\title{
White-Trash Autoethnography: An Analysis of CRT Fact and Logic Flaws
}

\author{
Biff Baker \\ Metropolitan State University of Denver
}

This autoethnography represents a strong counternarrative to the fiction that society tells about Whitetrash (a.k.a. poor whites in the bottom income quintile). The stories told about White-trash males in school and society wrongly reflect a master narrative that portrays these students as lazy, incompetent, low class, or low-intellectual individuals who care very little about education. My counternarrative challenges this portrayal by highlighting personal struggles to move ahead despite the racism and discrimination directed against a White-trash male within a public school system that is located within a predominantly black neighborhood. This research continues with analysis of critical race theory's fact and logic-flaws; and it concludes with calls for action against discrimination. This paper expands discourse in critical white studies by addressing preconceptions that marginalize white-trash people, which is a legitimate and necessary function of academic discourse.

Keywords: white trash, autoethnography, counternarrative, logic, critical race theory, critical white studies

\section{INTRODUCTION}

This autoethnography represents a strong counternarrative to the fiction that society tells about Whitetrash (a.k.a. poor white in the bottom income quintile). The stories told about White-trash males in school and society wrongly reflect a master narrative that portrays these students as lazy, incompetent, low class, or low-intellectual individuals who care very little about education. Part 1 is a counternarrative that challenges this portrayal by highlighting personal struggles to move ahead despite the racism and discrimination directed against a White-trash male within a Chicago public school that was located within a predominantly black neighborhood. Part 2 is an overview of Critical Race Theory (CRT) tenets and factual flaws; Part 3 of this research continues with analysis of critical race theory's logic-flaws. The paper concludes with calls for action to improve White-trash equality, inclusion, and justice.

\section{Critical Race Theory Components}

Derrick Bell, Alan Freeman, and Richard Delgado were the early founders of what is now called Critical Race Theory (CRT). So, what is CRT in the eyes of the founders? The CRT movement "is a collection of activists and scholars engaged in studying and transforming the relationship among race, racism, and power" (Delgado, et al, 2017, p. 3). The key idea is to identify who has power and who does not. Delgado and Stefancic (2017) write that CRT has three major components:

1) "Racism is ordinary, not aberrational - means that racism is difficult to address or cure because it is not acknowledged" (e.g., racism is a real and normal part of daily life in the United States) $(2017$, p. 8) 
2) Sometimes called interest convergence or material determinism, adds a further dimension. Because racism advances the interests of both white elites (materially) and working-class whites (psychically), large segments of society have little incentive to eradicate it. (e.g., white supremacy is an all-encompassing and omnipresent system of privilege) $(2017$, p. 9)

3) The "social construction" thesis, holds that races are categories that society invents, manipulates, or retires when convenient (e.g., opposition to liberalism's equality as support for an equity society) $(2017$, p. 9$)$

\section{FIGURE 1 CRITICAL RACE THEORY (CRT) CATEGORIES}

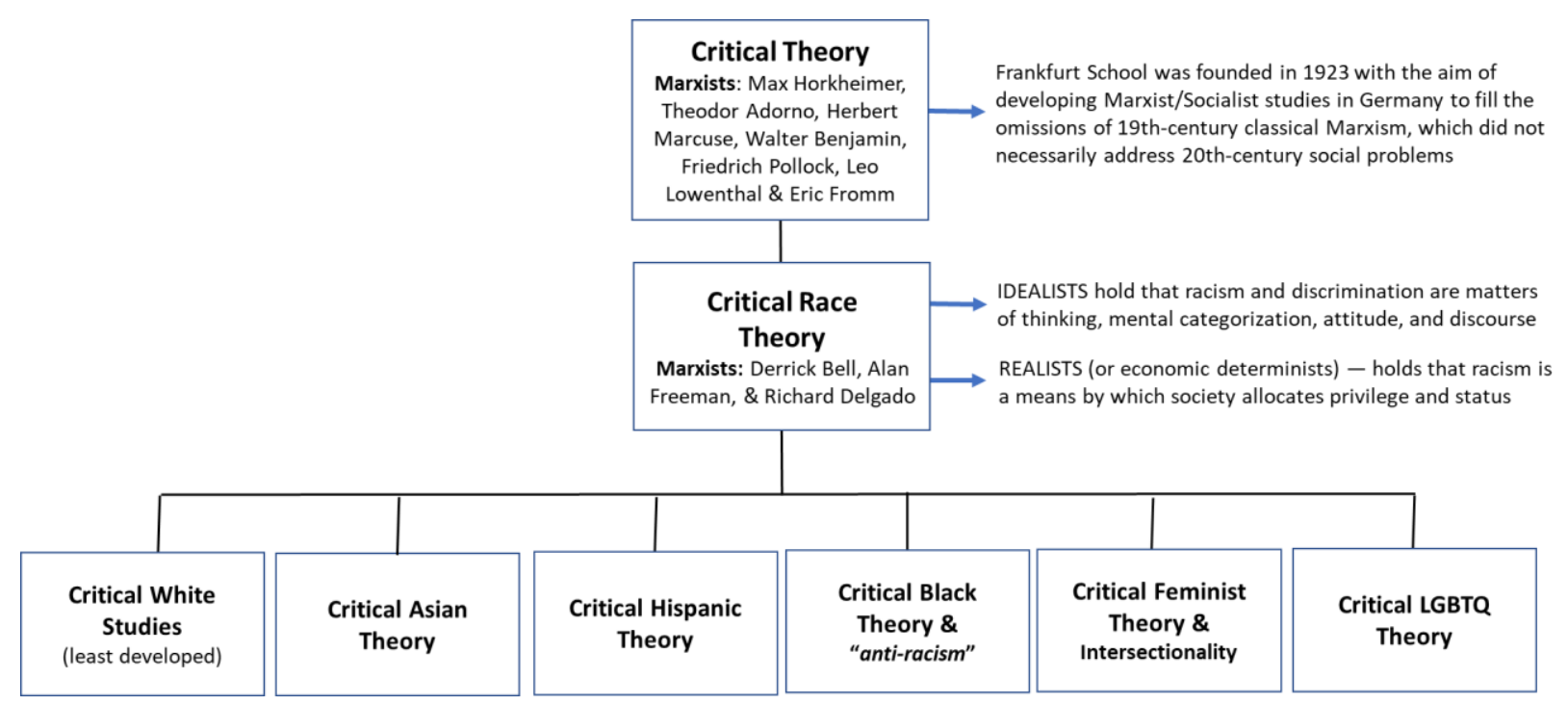

Delgado and Stefancic (2017) wrote that "minority status ... brings with it a presumed competence to speak about race and racism." Hence this study is designed to bring better understanding of white-minority, poor people, who live in black-majority neighborhoods. The study will expand discourse on critical white studies (Figure 1), which has a dearth of information and a wealth of misinformation about whites in poverty. Hopefully, this autoethnography will bring greater understanding to those who live in an academic echo chamber wherein all whites are privileged, and all blacks are victims, which is both illogical and not true (Lesperance, 2020, p. 6).

\section{THE AUTOETHNOGRAPHY AS A COUNTERSTORY}

The use of a narrative and storytelling are key components of CRT. Stories, using the lens of race, are often used to oppose conventional wisdom. Autobiographies, such as My Life as A Slave by Frederick Douglass have had powerful impact upon the understanding of majority and minority populations alike (Fisch, 2007; Stepto, 1991, Jennings, 2014). An autobiography gives marginalized populations voice to expose struggle and oppose injustice. The life experiences exposed in an autoethnography narratives permit a more rational exploration of oppressed individuals and potentially the communities in which they live. Just as many rappers claim to have taken the power out of the $\mathrm{N}$-word and transforming the slur into a term of endearment for many black people (especially rappers). I am reclaiming my childhood identify as "whitetrash" and embracing this as an initial obstacle, and a subsequent a badge of honor that I was able to overcome. Other White-trash people have not been as blessed in part due the government's systemic racism implemented through affirmative action mandates since 1965. 


\section{Autoethnography Part 1 - Grammar School}

I was raised by my mother in the 1950s and 1960s in one of the poorest neighborhoods in Chicago. My mother earned \$1.00 per hour as a waitress and any other income was a result of tips from customers that were often almost as poor as we were. Eventually, my mother found a waitress position in a middle-class neighborhood, and she would say that a $10 \%$ tip from an expensive meal is much better than $10 \%$ in a cheap diner. Her emphasis on living off tips was my first exposure to math, and I loved it. But one of my earliest memories was my mother coming home and crying hard for what seemed like an hour. All four of us small children gathered around her for a group hug; and we asked why she was crying. She said she had been a server for a ten-person dinner party for over 3-hours, and they had a bill of $\$ 300.00$, but they only left her a \$1.00 tip: cheap twits. She cried because we did not have enough money to buy food and pay the rent. My father had left early in our lives and sent child support only if he felt like it, but that was not often. At six years old, my siblings and I understood what it was to be poor and hungry.

My grammar school was about a mile from our home. My mother usually took a city bus to work, so her four children walked to school every day. Some days we made it to school without incident, and on other days, older and bigger kids would steal our lunches and demand our milk money. Since we were poor, we seldom had milk money, so eventually the bullies left us alone. Part of being destitute is malnutrition, which means kids are often skinnier and smaller than the bullies. By age eight, I was acutely aware that we were poor and that both bullies and victims existed - I realized that my siblings and I were all in the victim category as measured by our recurring bruises, black eyes, and bloodied lips.

I took great joy in going to school. There was no air conditioning in the summer, but in the winter, I had a warm, dry, and quasi-safe place to learn. My grammar school was about 50\% black and 50\% white or Hispanic; for in the 1960s, white and Latino were considered synonymous (Gonzalez, 2021, p 19). The grammar school had a recess period in the middle of the day, and I always dreaded it, because the bigger kids would beat up smaller kids for money or just for fun. If teacher supervision existed, then it was invisible to me, because I ended up with many black eyes and bloody noses. I failed reading in the first grade, which became a turning point in my life. Since I had a bright red "F" on my report card, my mother attended a parent-teacher conference, wherein they decided that I should forfeit recess and stay inside to read. I was thrilled, because my punishment allowed me to escape an inner-city, playground version of Lord of the Flies. That was the only "F", that I have ever received in my life, but for me, it taught me the concept that practice makes perfect.

The remainder of my grammar school years were spent in the library as often as possible. The more time I spent in the library, the less time I was bullied, and the higher my grades climbed: it was a win-win. Reading in the library seemed to be the lifeline to my existence as a short, skinny kid with malnutrition and no muscle. My mother always left for work before us kids left for school; and she always returned 1 to 2 hours after we came home from school. So, her top rules were to do homework as soon as we got home, and never let anyone into the house: never! Fear of danger-stranger as well as fear of being kidnapped by Child Protective Services, resulted in an isolated childhood, without many friends external to my siblings.

Poverty did not permit us to join any sports, clubs or even the boy scouts. Neighbors, both black and white, always shunned us as the white-trash or trailer trash of the neighborhood. However, when I was in $4^{\text {th }}$ grade, my mother had saved enough to buy me a used bicycle at the Good-Will Store. It cost $\$ 4.00$, which I now realize was $10 \%$ of her weekly pay and that was a lot to sacrifice for a bike. I was allowed to ride to the end of our city-block but not further. One day, I pedaled up a tall bridge that spanned across a nearby interstate highway, just for the joy of riding back down at breakneck speed. At the bottom of the bridge were three older teens, who beat me up, called me racial slurs, and stole my bike. I never felt safe again in my own neighborhood, and always admonished my younger brother and sister when they wanted to play outside.

The most significant events in my grammar school memories were the Cuban Missile Crisis, and the deaths of John F Kennedy, Malcolm X, Martin Luther King, Jr., and Robert Kennedy. I turned six years old during the Cuban Missile Crisis, and distinctly remember being told to hide under my desk whenever sirens went off. Looking back on this many years later was laughable, because the public-school teachers taught kids to hide under desks in case of a nuclear missile strike. Absurd, because a nuclear blast would 
have vaporized the kids and their desks! I was just starting 2nd grade at the time of the President Kennedy's assassination in 1963. Then, Malcolm X was killed on February 21, 1965; Dr. Martin Luther King, Jr. was assassinated April 4, 1968; finally, Robert Kennedy was assassinated on June 6, 1968. So, from the 2nd to 6th grade, the world was looking like a very scary place. On the day Dr. King was assassinated, white kids were sent home early from school due to fears of retaliation or vigilante violence by the majority-black population in our neighborhood. As an 11-year-old child, I was cornered and beaten severely, with three boys screaming racial epitaphs during every blow to my face and body, due to my alleged white supremacy. I did not feel safe in my own neighborhood, but my mother taught me to despise the perpetrators, not an entire race. Despite a lack of formal education, my mother was enlightened.

\section{Autoethnography Part 2 - High School}

I went to a high school in which the principal was black; our teachers and student body were predominantly black as well. Whites were a majority in the United States, but in my predominantly black neighborhood, I was a minority. I was reminded of my white-trash minority status by black students weekly. Racism, prejudice, and discrimination by blacks against non-blacks (Whites, Hispanics, and Asians) was a norm in my high school - their hate was based on color, not character, or behavior. I experienced daily microaggressions from many students and select black teachers; getting beaten up was a daily threat. I continued my habit of spending a lot of time in the library, which resulted in all "A" grades in high school. Without knowing the technical term at the time, I became a true believer in meritocracy, because the time I invested in homework, paid off in excellent grades.

My high school was predominantly black, so our American history and civics classes already included 'black history' as it is known today in academia. I learned about Frederick Douglass at a very early age, and I held him up as my hero for the rest of my life. As I read, My Life as a Slave, I marveled at the fact that he strove to learn to read despite laws to the contrary; to me that was the mark of a true hero. At 13 years old, after reading his autobiography a second and third time, I decided that I would get as much education as possible, become a self-sufficient businessman, and never be poor again. Literally, Frederick Douglass became the model for my own life: if he could escape slavery, then I resolved that I could escape poverty. In class, we discussed slavery and reparations, but the white students were often silenced and stigmatized. I was called upon by the teacher, and I quoted from Ezekiel 18:20: "The son will not share the guilt of the father, nor will the father share the guilt of the son. The righteousness of the righteous man will be credited to him, and the wickedness of the wicked will be charged against him." Thereafter, I was silenced by my black friends and peers for several weeks. As a kid in a predominantly black school, I had done a lot of research and I knew that only $1.5 \%$ of Americans were slaveowners per the 1860 census; and as recent immigrants, my family and my ancestors had nothing to do with American slavery. So, as a whitetrash child of poverty, I never understood the animosity and hatred from my black classmates and fairweather friends. It was not until my college days that I learned that according to the Trans-Atlantic Slave Trade Database, that about 388,000 African slaves were transported directly to the United States from 1619 to 1808, yet Brazil received almost half of the 10 million that went to Latin America (Gates, 2017, p. 9). It made me question the politicized people of color (POC) narrative that artificially unites African Americans and Latino populations in political diatribe, after all Latin America had 25 times more slaves!

There were several protests and a few riots in my high school during the early 1970s; some of the demonstrations-turned-riots were protests over the Viet Nam war, whereas some were racially motivated but as an outsider, I was assaulted but never understood why. My teachers often avoided tough questions, especially if it was asked by a white-trash male student. Since my mother raised us in a liberal tradition, I believed in color-blindness, equality under the law, and individual rights. My school was academically one of the lowest ranked in Chicago, yet we were taught about Martin Luther King, Jr., and the civil rights movement; and many kids in school could recite the "I have a Dream" speech. My inner-city high school teachers emphasized the verse, "I have a dream that my four little children will one day live in a nation where they will not be judged by the color of their skin, but by the content of their character." I recall earning an "A" for a composition that I wrote on character. Unfortunately, there were many in my neighborhood and school who completely rejected King's words and followed the more radicalized or 
militant path of Black Liberation Theology, which taught that all whites were bad. In my school, hate speech included a torrent of insults, epithets, and name-calling that white-trash kids faced daily. The non-stop hate speech, microaggressions, and physical assaults against White-trash people in a black neighborhood created a world wherein non-blacks were continuously on the defensive both physically and mentally resulting in what is now called post traumatic syndrome, and race fatigue (Steele, 2017).

I was raised by a mother, who was a minimum-wage employee, and relatively uneducated. I had no male influences after my father left, for he did not return. The one person who took me under his wing was a large, black, retired Army Master Sergeant who taught the Junior Reserve Officer Training Corps (JROTC) program. At 13 years old, I was eager for adult-male guidance that I did not receive at home. This Master Sergeant was the person who gave me the 'black boy speech' as it is called today: obey the police; do what they say; do not make sudden movements; and (again) obey the police. He also told me that as a white boy, to avoid gangs, do not go out at night, do not drink, or use drugs, and that running from violence was not cowardice. I obeyed my Master Sergeant's rules, but during my four years in high school, I was severely beaten seven-times, with one instance of being beaten-up by a Chicago police officer (I was nearby a fight, but not involved). In each of these seven beatings, I endured racial slurs and I was merely guilty of being white-trash and in a Black neighborhood. My neighborhood was dominated by the Disciples and the Latin Kings gangs, not the police, or law and order.

I had no connections, no job prospects, and no wealthy benefactors (friends or relatives), so after I joined the Reserve Officer Training Corps (ROTC), I decided to volunteer for the Viet Nam war after graduating from high school. Most appealing to me was that the US Army would feed me three times a day, and I would earn a paycheck. I had two other goals: I wanted to learn how to fight, so that I would never be a victim again; also, I wanted to protect and defend American values as well as our besieged allies in South Viet Nam. I wanted to spread the concepts of classical liberalism (equality and liberty) through-out the world. Finally, I felt it would be safer in Viet Nam with a military-issued rifle than living in Chicago without a firearm. Chicago had strict gun laws, which did not help the poorer-working class: we could not defend ourselves from gangs and violent crime, and the police always arrived too late. Eventually I understood that gun-control laws placed the working poor of all hues at the greatest disadvantage; after all, the rich of any color could hire a bodyguard, but poor people cannot (Lott, 2000).

After turning 16 years old, I worked full time with up to 40 hours a week as a stock-boy, and another 40-hours a week were spent in class or at the library. I graduated number two out of a high school class of almost 1000 students. My family thought it was a big deal, but I later discovered that the academic standards had dropped so low in my inner-city Chicago high school, that my "A+" 4.0 average was probably equal to a 3.0 GPA anywhere else. This is the harm caused by the low expectations of anyone who is being raised in a poor neighborhood and the academics who make excuses for the poor, rather than supporting merit.

Shortly after departing Chicago for the military, my cousin was raped and murdered by a black gang. She was at a convenience store when a group of men burst in with shot guns. They killed her fiancé, and then dragged her into a tenement for a gang-rape. After satisfying their primal lusts, they placed a gun to her head and pulled the trigger. Once again, my mother taught me to hate the gang bangers, not an entire race.

Several years later, my younger brother died of a drug overdose. I had joined the military and walked the straight and narrow; he had joined a gang, became a drug user, and died an early death. Equality? No! Dr. Sowell asked, "If there is not equality of outcomes among people born to the same parents and raised under the same roof, why should equality of outcomes be expected, or assumed, when conditions are not nearly so comparable?" (Sowell, 2019, page 7). My family suffered under a dysfunctional local government without any type of social or economic privilege. Also, white-trash males did not qualify for affirmative action quotas, no matter how poor. Being raised as a white-trash male in America, feels like running a race where the government keeps moving the finish line; or a race where black people are now given a 100meter head start due to affirmative action, with most of white America at a starting line, but white-trash people are held back 200-meters behind the starting line, with 50-pound weights tied to each ankle. From a White-trash perspective, affirmative action mandates did not harm the rich of any hue, but instead they harmed poor white-trash males more than any other demographic. While CRT advocates claim to fight 
unwarranted exclusionary criteria (Crenshaw, 2017, p. 2316), poor White-trash males, who are at the bottom of the economic pyramid, continuously must fight against the unwarranted exclusionary criteria of affirmative action quotas and CRT generated biases and discrimination.

\section{Autoethnography Part 3 - My Escape From a Dystopian Neighborhood}

I joined the military, but did not deploy to Viet Nam for on April 30, 1975, the last few Americans still in South Vietnam were airlifted out as Saigon fell to communist forces: like Afghanistan in 2021, it was a political, not a military defeat. None-the-less, it was in the military that I grew into the man that I am today. When I joined, I was 5' 6" and 110 pounds; but after eating 3-meals per day and constant exercise during boot camp, I developed into 150 pounds of muscle just 8-weeks later. I learned how to shoot; how to do hand-to-hand combat; and how to work as a member of a team. The military taught me the difference between good and bad leaders, as well as effective and ineffective teams; and with the fullness of time, I learned to lead soldiers. I was surprised to learn that race relations in the military during the Viet Nam era, were at times as bad as they were in my high school.

After joining the military, I earned a Bachelor of Science degree, next a Master's in Business and finally a Doctorate in Management. I completed 26 years of military service, and then I worked 14 years in corporate America, before starting my own business. While my autoethnography narrative painted the picture of being a white-trash, or a poor-white male, I am also part Hispanic and part African - however, I learned not to use these two identities due to abuse from my peers. My DNA test and the one-drop rule (hypodescent) says that I am part African, but my high school peers insisted that I was "never Black enough" - I later learned about the light versus dark skin biases among blacks (Capretto, 2014) and to my knowledge I am neither the descendant of American slaves, nor slave owners; so, like Kamala Harris, I am not "African-American" as defined by leftists today. I am also part Irish and Latino, but I have been reminded my entire life that I was "never Latino enough and not La Raza." My DNA says otherwise, but having been silenced by my bigoted peers, and simultaneously not wanting to be labeled as a race traitor, I was labeled White-trash as a child, and then passed as a white male for 45 years, but I now have reclaimed my voice. Unlike either Elizabeth Warren (fake Native American) or Rachel Dolezal (fake Black woman), I am a multiracial person; and unlike both Barack and Michelle Obama, I grew up in a predominantly black and impoverished neighborhood. Wealthy Barack and Michelle would qualify for affirmative action quotas, but I would not. Nor have I ever used claims of race or ethnicity for scholarships, school admissions or to boost my career. My learned culture as a child was predominantly inner-city black, yet I remained "the other" within my own neighborhood.

My white-trash upbringing gave me more than a double-consciousness - the ability to see events from the perspective of the majority as well as the minority (DuBois, 1994). I developed a triple-consciousness, for in my neighborhood the majority population and the powerful were black, whereas the poor and uneducated who lacked power included White-trash peoples. Eventually, I married a person-of-color, who grew up in an impoverished environment as well. Our children are multiracial (African, Latino, Asian, and Caucasian), and one is LGBTQ: nonetheless all of us feel immensely blessed to be American citizens.

\section{CRT \& CRITICAL WHITE STUDIES - AN ACTIVIST'S CRITIQUE}

A critical analysis of any body of knowledge is required to obtain a terminal degree, so many doctoral candidates have a paradigm shift simply based on reading thousands of pages of data or information on any chosen topic. In my case, I read thousands of pages of quantitative data and qualitative studies related to total quality management (TQM). An important finding was that TQM works without regard to age, race, ethnicity, nationality, or gender, hence there are universal truths regarding both products and services.

In contrast, critical race theory is based primarily upon biased opinions, not facts. As a classical liberal and an activist for equality, I disagree with opinion-based components of the theory - and only through truthful critical analysis, can we make any idea better. Unfortunately, I anticipate being silenced by nonliberal political authoritarians, who pose as woke academics. Those who try to silence dissent with ad hominem attacks are the equivalent of NAZI overlords or modern-day dictators as in Venezuela, Cuba, or 
North Korea. I do not lose sleep over those bigot's opinions; whereas polite, and informed discourse is always welcome.

\section{Issue \#1: Racism Is Ordinary \\ Point}

CRT authors, Delgado and Stefancic (2017) wrote that "racism is ordinary and ... not acknowledged" or alternatively that racism is a real and normal part of daily life in the United States (2017, p. 8).

\section{Counterpoints}

Counterpoints: There is no data to support this opinion, so the entirety of CRT is at risk because its key premise is based upon opinion, not fact. Based on my experiences, blacks and whites played together in grammar school, but due to racialization, the rift between black and white grew in high school. Hence, racism, prejudice, and discrimination were learned.

The most intimate relationship among human beings is marriage, and opinions related to interracial marriage have changed. Pew Research (2017) determined that Americans in greater numbers are accepting of interracial relations - such as, a close relative who wants to marry a person of a different race. In 2000, $31 \%$ of Americans said they would oppose a close relative marrying someone of a different race or ethnicity; yet, by 2017, only 10\% would oppose an intermarriage within their family. As recently as 1990, roughly six-in-ten nonblack Americans (63\%) said they would be opposed to a close relative marrying a black person; that number dropped to 14\% in 2017 (Pew, 2017, p. 13). This could not happen if racism was ordinary, and not aberrational. Delgado and Stefancic (2017) contend that "racism is difficult to address or cure because it is not acknowledged," whereas I contend that racism is not difficult to address, however much perceived racism and discrimination has multiple explanations other than race.

\section{Issue \#2: White Supremacy and Privilege \\ Point}

CRT authors Delgado and Stefancic (2017) wrote that (white) "racism advances the interests of both white elites (materially) and working-class whites (psychically), large segments of society have little incentive to eradicate it" $(2017$, p. 9) and that white supremacy is an all-encompassing and omnipresent system of privilege.

\section{Counterpoints}

Delgado and Stefancic (2017) wrote that "white privilege refers to the myriad of social advantages, benefits, and courtesies that come with being a member of the dominant race" $(2017$, p. 89) and that "scholars of white privilege write that white people benefit from a system of favors, exchanges, and courtesies from which outsiders of color are frequently excluded" (2017, p 90). Both attempts to define the now-common term "white privilege" have numerous examples in today's headlines that negate the concept of privilege, but CRT theorist dismiss any other narrative (Tate, 2021). Based upon my own White-trash autoethnographic narrative, what privilege did I have as compared to a mixed-race man, who self-identified as black, graduated from Harvard, and became President of the United States (POTUS)? None! My uneducated mother and absent, deadbeat dad could not compare to the Ph.D. mother and multi-millionaire stepfather of the former POTUS. So why would CRT advocates insist that I had privilege and the former POTUS did not? Obviously, children are poor or uneducated due to their parent's socio-economic status, not their race. 


\section{FIGURE 2}

AMERICAN PRIVILEGE

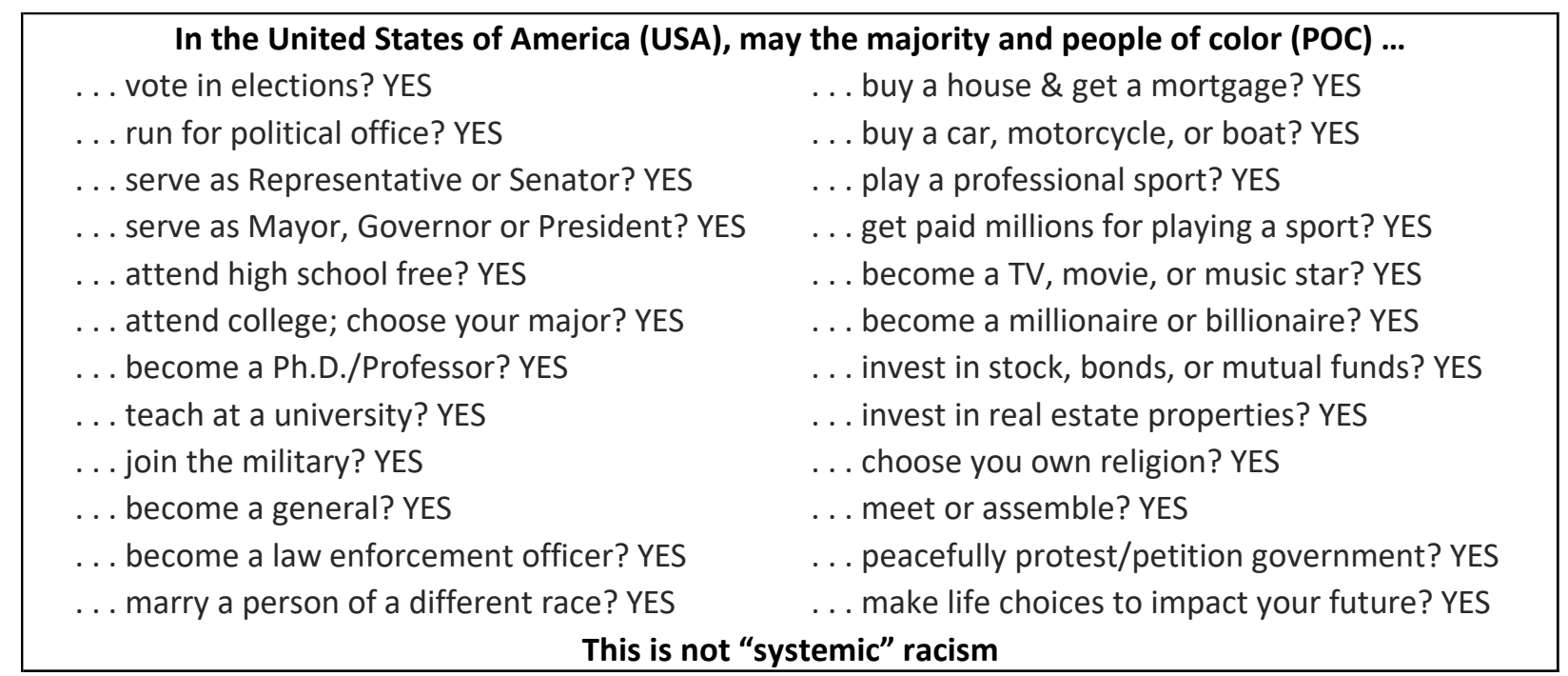

Feminist Peggy McIntosh wrote a now-infamous list wherein she theorized that white people enjoy and can rely on numerous privileges that people of color cannot. I took McIntosh's challenge and out of 26 questions, my responses were 1-Yes; 20-No; 4-Not Always; and 1-Not Applicable. Remember that my responses are of a white-trash child who was raised in a predominantly black neighborhood in Chicago; not a black man raised in a white suburb. Peggy McIntosh, pay attention: every American citizen has the privileges listed in Figure 2.

I would gladly compare my responses to her biased survey with the responses of our former POTUS. If white privilege is "a system by which whites help and buoy each other up" (Delgado et al, 2017, p. 90), then one could also argue that in a black neighborhood, with a black mayor, black chief of police, black store owners, black principal, and teachers, that black privilege exists? Yes! So, we could define Black privilege is a right or advantage, often unwritten, conferred on some people but not others, usually without examination or good reason; it includes benefits, such as affirmative action quotas and race-based scholarships, a system by which blacks help and buoy each other up. Nkechi Amare Diallo (Rachel Dolezal) is a perfect example of a white woman seeking Black privilege. As an aside, when I was in Korea, I observed Korean privilege; in China, Chinese privilege; in Kuwait, Arabic-Muslim privilege; or in Latin America, Latino/a privilege. This is merely part of human tribalism, nothing more. Rather than lamenting over the color of a bandage, Ms. McIntosh would do better using the proposed list of questions found at Figure 2 called American Privilege to educate, rather than indoctrinate her students.

\section{Issue \#3: Systemic Racism \\ Point}

Delgado and Stefancic (2017) contend that critics of CRT identify affirmative action as a case of reverse discrimination against whites. They write the unspoken premise behind reverse discrimination is that white people are innocent. CRT "theorists and social scientists hold that racism is pervasive, systemic, and deeply ingrained. If we take this perspective, then no white member of society seems quite so innocent" (Delgado et al, 2017, p. 91). 
FIGURE 3

SYSTEMIC RACISM COMPARISON: GERMAN NATIONAL SOCIALISTS VERSUS USA

\begin{tabular}{|c|c|c|}
\hline & $\begin{array}{c}\text { NAZI Germany 1940s } \\
\text { Jews + Other Minorities (JoM) }\end{array}$ & $\begin{array}{c}\text { USA } 2022 \\
\text { People of Color (POC) }\end{array}$ \\
\hline Free Speech & $\begin{array}{l}\text { Arrest and imprisonment of JoM or anyone } \\
\text { oppossed to National Socialists }\end{array}$ & $\begin{array}{l}\text { POC can peacefully protest and speak } \\
\text { critically of the US Government }\end{array}$ \\
\hline Self Defense & $\begin{array}{l}\text { Registration, then confiscation of JoM } \\
\text { weapons }\end{array}$ & POC can own guns unless convicted of felony \\
\hline Private Property & $\begin{array}{l}\text { Confiscation of JoM possessions, houses, and } \\
\text { businesses }\end{array}$ & POC can own homes and start businesses \\
\hline Health Care & $\begin{array}{l}\text { Denial of health care to JoM; medical } \\
\text { experimentation on JoM prisoners }\end{array}$ & $\begin{array}{l}\text { POC can register for Medicaid; elder POC } \\
\text { get Medicare }\end{array}$ \\
\hline Wealth & $\begin{array}{l}\text { Confiscation of JoM Wealth (all types of } \\
\text { stocks, bonds, silver, gold, land, etc) }\end{array}$ & $\begin{array}{l}\text { POC can become millionaires and billionaires } \\
\text { - taxes, but no confiscation }\end{array}$ \\
\hline Due Process/Death & $\begin{array}{l}\text { JoM sent to concentration camps and gas } \\
\text { chambers; death by edict; Holocaust genocide }\end{array}$ & $\begin{array}{l}\text { POC accused of crimes receive free legal } \\
\text { representation }\end{array}$ \\
\hline Citizenship & $\begin{array}{l}\text { JoM were considered subhumans who could } \\
\text { not vote or hold office }\end{array}$ & POC vote and hold elected office \\
\hline Immigration & $\begin{array}{l}\text { JoM attempted to escape National Socialist } \\
\text { (NAZI) Germany }\end{array}$ & $\begin{array}{l}\text { POC gladly immigrate to the USA (both } \\
\text { legally and illegally) }\end{array}$ \\
\hline "Systemic" Results & $\begin{array}{l}\text { NAZIs killed } 25 \text { million from } 1939 \text { to } 1945 \\
\text { almost } 6 \text { million Jews murdered in six years }\end{array}$ & $\begin{array}{l}\text { British enslaved 388,000 blacks; in } 1865 \\
\text { over } 3.9 \text { million blacks emancipated by USA }\end{array}$ \\
\hline & \multicolumn{2}{|c|}{ See Gates (2017); Halbrook (2013); and Courtois and et. al. (1999) } \\
\hline
\end{tabular}

\section{Counterpoint}

On behalf of the white-trash community in this country, I strenuously deny that any of us melanindeprived, poor people have benefited from the nebulous concept of white privilege and systemic racism. The issue with CRT theorists is that they have a deeply ingrained belief that "racism is pervasive, systemic, and deeply ingrained (and that) whites are not innocent" (Delgado et al, 2017, p. 91), but they lack any tangible proof for their outrageous assumption. There is no historical context to the CRT claim that racism in the U.S.A. today is 'systemic.' Therefore, Figure 3 is provided to show a historical example of tangible systemic racism by the German National Socialists (NAZI) against the Jews and Other Minorities (JoM) (Halbrook, 2013) in the 1940s, as contrasted with People of Color (POC) in the USA in 2022. Per Figure 3, German National Socialists were demonstrably racist; whereas CRT's alleged systemic racism in the USA today is merely hyperbole.

While CRT theorists claim that white people stereotype Blacks; they simultaneously stereotype with fixed, usually negative, images all members of the white race - CRT uses Orwellian newspeak or double speak. Parental concern over teaching CRT to children largely comes from CRT advocate's implicit bias, or unconscious association of one idea with another, such as race which, frequently evinces a negative attitude against white people. Theorizing that "no white member of society seems quite so innocent" is a bigoted example of the hasty generalization fallacy (a.k.a. over-generalization fallacy): CRT theorists cannot make this claim and say that something is true about an entire race, without tangible, measurable, or overt examples of evidence. This CRT tenet is also reminiscent of German National Socialists (NAZIs) stereotypes of Jews in the last century. 


\section{Issue \#4: Race and Income}

\section{Point}

Delgado and Stefancic (2017) write that "the gap between whites and nonwhites in income, assets, educational attainment, and life expectancy is as wide as it was thirty years ago, if not wider" (Delgado et al, 2017, p. 48). CRT theorists do not provide factual documentation for this assertion, so the following paragraphs expose their lies by explaining income by race within the United States.

\section{Counterpoints}

The median income of black families in 1960 was 55 percent of the whites' median income. Today, when comparing the pay for black and white men with the same education, qualifications, experience, and job that were in the same geographic location, black men earned 98 cents for every dollar earned by white men in 2020 (Miller, 2020). The 2019 Census data separates income by race into quintiles. The White working population consists of 100,568,000 people, so one quintile is 20.1 million workers; the Black work population consists of 18,055,000 people, so one quintile is 3.6 million; the Hispanic work population consists of 17,667,000 people, so one quintile is 3.5 million; and finally, the Asian work population consists of 6,853,000 people, so one quintile is 1.4 million as shown in Figure 4.

The lowest ranked quintile of Black workers makes up to $\$ 17,000$ per year; the lowest Hispanic quintile makes up to $\$ 25,000$ per year; the lowest White quintile makes up to $\$ 30,000$ per year; and finally, the lowest Asian quintile makes up to $\$ 40,000$ per year. CRT theorists will quickly identify those blacks in this quintile make $44 \%$ less than whites; Hispanics make 17\% less than whites; but the lowest earning Asians make 33\% more than the lowest earning Whites. Yet, CRT theorists claim that this is an example of racism.

Using numbers and statistics can have alternate interpretations; for instance, the top 12.6 million blacks make more, or substantially more money, than the bottom 20 million poor whites. Statistically more blacks are poor, but numerically more whites are poor. As a former member of white-trash (who was raised in the lowest half of the bottom quintile), I constantly saw black children with two parents, a new car, a nice home, and enough to eat - several privileges that my family did not experience.

Another inconvenient fact hidden by CRT proponents is that if all races in the United States were judged based upon income, then Hispanic-Americans would have the $11^{\text {th }}$ largest GDP in the world (on par with Russia); African Americans would have the $15^{\text {th }}$ largest GDP in the world (on par with Spain); and our tiny Asian-American population would have the $17^{\text {th }}$ largest GDP in the world (between Mexico and the Netherlands)! Of significance, CRT theorists have not explained why, when looking at Median Household Income by detailed ancestry, that Ghanaian Americans make $\$ 69,021$, Nigerian Americans make $\$ 68,658$, but White-Americans only make $\$ 65,902$ median income (ACS, 2019; Tate, 2021, p. 18). Why? African immigrants prioritize language and education (Tarlebbea, 2010; Tate, 2021, p. 9). These quantifiable facts negate the absurd CRT hypothesis that African Americans have made no progress in 30 years and are mileposts for the differences between race versus culture as critical indicators of success. Individualism, objectivity, rationality, reason, hard work, the nuclear family, a belief in progress, a written tradition, politeness, the justice system, respect for authority, delayed gratification, and planning for the future, among others should be considered "American culture" regardless of hue, not white culture (Tate, 2021, p 46). 


\section{FIGURE 4 \\ US INCOME BY RACE}

\begin{tabular}{|l|r|r|}
\multicolumn{1}{c}{$\begin{array}{c}2019 \\
\text { Census } \\
\text { Data }\end{array}$} & \multicolumn{1}{c}{$\begin{array}{c}\text { Work } \\
\text { Population } \\
(000)\end{array}$} & $\begin{array}{c}\text { One Fifth } \\
(20 \%) \\
\text { m }\end{array}$ \\
\begin{tabular}{|l|r|} 
Asian \\
millions
\end{tabular} \\
\hline White & 6,853 & 1.4 \\
\hline Hispanic & 100,568 & 20.1 \\
\hline Black & 17,667 & 3.5 \\
\hline
\end{tabular}

\$276K (Upper Class)

\begin{tabular}{|c|c|c|c|}
\hline \multirow[t]{2}{*}{$\$ 198 K$} & \multirow[t]{2}{*}{$\$ 201 K$} & & \multirow{2}{*}{ \$192K } \\
\hline & & \$147K (Upper Middle Class) & \\
\hline \multirow{5}{*}{$\$ 100 \mathrm{~K}$} & \multirow{4}{*}{$\$ 111 \mathrm{~K}$} & & \\
\hline & & & \\
\hline & & $\$ 90 \mathrm{~K}$ (Middle Class) & \\
\hline & & & \$78K \\
\hline & \multirow[t]{2}{*}{$\$ 69 \mathrm{~K}$} & & \\
\hline \multirow[t]{2}{*}{$\$ 58 \mathrm{~K}$} & & \multirow{3}{*}{ \$56K (Lower Middle Class) } & \\
\hline & \multirow[t]{2}{*}{$\$ 45 \mathrm{~K}$} & & \\
\hline \multirow[t]{2}{*}{ \$35K } & & & $\$ 40 k$ \\
\hline & \multirow[t]{2}{*}{ \$25K } & \multirow[t]{2}{*}{ \$30K (Lowest Quintile) } & \\
\hline \$17K & & & \\
\hline $\begin{array}{c}\text { Blacks }=3.6 \\
\text { million per } \\
\text { Quintile }\end{array}$ & $\begin{array}{c}\text { Hispanics }=3.5 \\
\text { million per } \\
\text { Quintile }\end{array}$ & Whites $=\mathbf{2 0 . 1}$ million per Quintile & $\begin{array}{l}\text { Asian 1.4 } \\
\text { million / } \\
\text { Quintile }\end{array}$ \\
\hline
\end{tabular}

In high school, I constantly heard the mantra "back to Mother Africa" from many of my friends and peers yet not one country in Africa has a higher social mobility rate than the USA (WEF, 2020). Despite the negativity propagated by CRT advocates, Blacks in the United States are doing much better than Blacks in Africa. The World Bank tracks per capita GDP, which is a global measure for gauging the prosperity of nations and is used by economists, along with GDP, to analyze the prosperity of a country based on its economic growth. Per capita GDP in the prosperous country of Nigeria is $\$ 2,097$ and worldwide it is $\$ 10,910$, but in the United States it is $\$ 63,413$ (The World Bank, 2021), which is why people emigrate from Nigeria to the United States, not vice versa.

In contrast to the CRT 'racism-drives-everything' narrative, individual life-choices were highlighted in recent studies that came to the conclusion that teens are much more likely to flourish financially if they follow the "success sequence" in this order - (1) getting at least a high school diploma; (2) working fulltime; and (3) marrying before having any children (AEI, 2017; Haskins, 2013). This success sequence seems straight forward, but there are millions of black, brown, and white Americans who have not been taught that this sequence will lead to success, or they choose to ignore it. In addition to the American Enterprise Institute and the Brookings Institute findings, the United States Census Bureau links poverty 
with out-of-wedlock births. If in a two-parent household labeled "Married couple families", then the percentage below the poverty line is $5.30 \%$ and in contrast "Families with female householder, with no husband present" is at $28 \%$ poverty rate! In 2016 , the percentage of nonmarital births varied widely among race and ethnic groups, from a low of $12 \%$ for Asian mothers to a high of $69.8 \%$ for black mothers, so race is not the only factor in poverty: personal choices matter as per this flow chart in Figure 5. The upper level is one's environment; the middle are choices that every individual makes, regardless of race; and the bottom lists possible consequences. A parent's bad decisions impact upon one's offspring substantially more that one's hue.

\section{FIGURE 5 \\ PERSONAL CHOICE FLOWCHART}

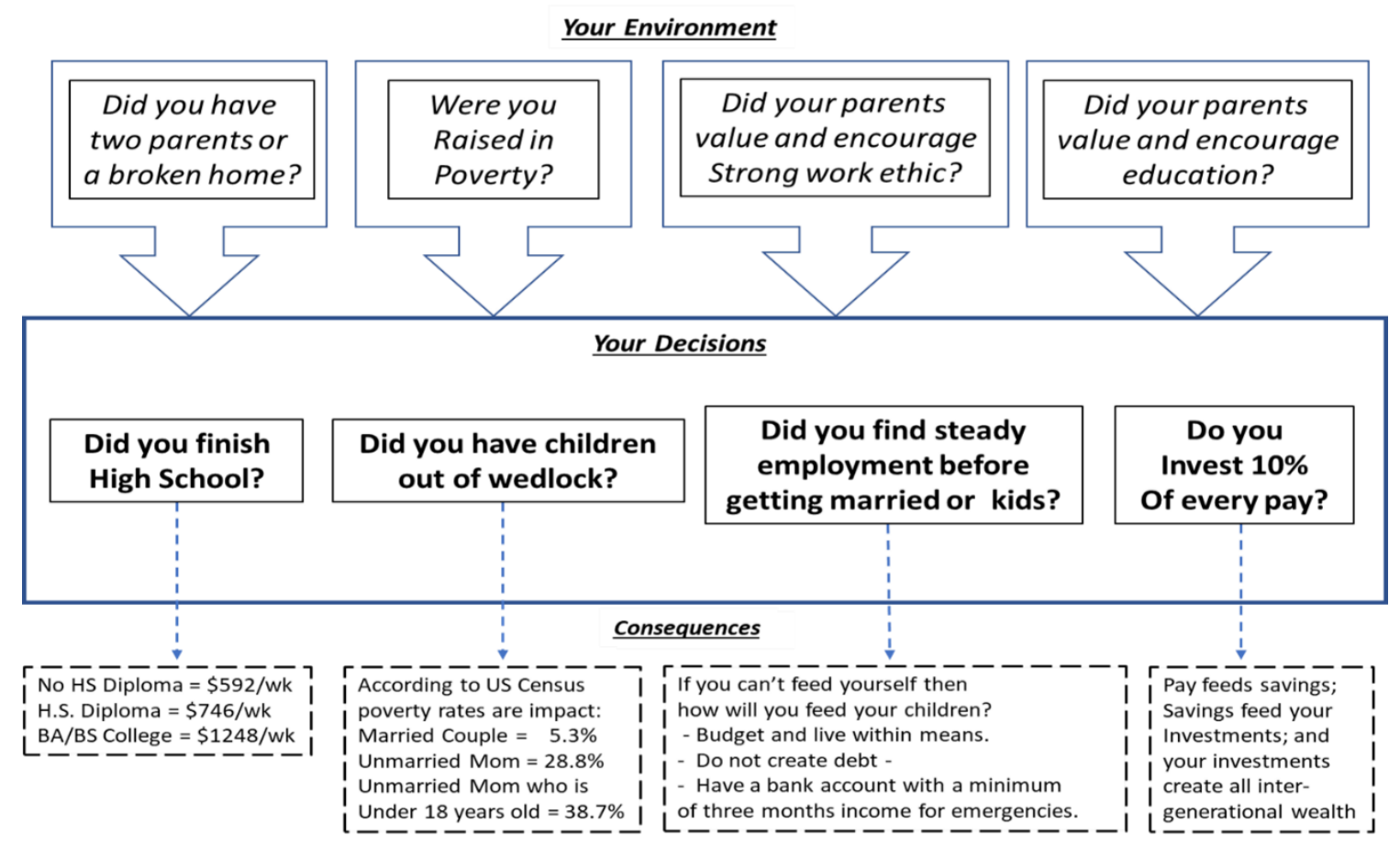

\section{Issue \#5: Crime}

Point

Delgado and Stefancic (2017) compare the viewpoint called the 'politics of respectability' that has a get-tough on crime attitude with the 'politics of identification' that want the community to handle offenders and advocate anti-snitching campaigns in black neighborhoods (Delgado, et al, 2017, p 62).

\section{Counterpoints}

I was raised in a crime laden neighborhood where most of my friends and relatives were victims of violent crimes such as assault, rape and murder, or property theft. Law-abiding citizens of any hue do not want to be victims, so they do not support the soft-on-crime narrative of CRT theorists, who may never have resided in a ghetto. According to a Gallup poll in June and July of 2020, $81 \%$ of blacks and $88 \%$ of whites want the same level, or more patrolling of their neighborhoods, not less (Saad, 2020).

Delgado and Stefancic (2017) try to deflect criticism of CRT by stating that white collar crime is much more serious than street crime. However, most people in violent communities are less concerned with losing money than losing their lives. The chart (Figure 6) shows that the biggest killers of whites are whites, and the biggest killers of blacks are blacks. However, when we divide the number of deaths by the population and compare these two figures, then we can see that a black is five-times more likely of being killed by a 
black, than a white being killed by a white (e.g., 2594/62 divided by 2574/12.5). These numbers are equally bad when we examine cross-racial murders because white victims are eleven times more likely of being killed by a black perpetrator, than vice versa (e.g., 566/12.5 divided by 246/62). White cops hunting blacks is a myth created by CRT propagandists; yet media has been gaslighting us for years (Tate, 2021, p 68). CRT advocates can wax philosophical about why crimes exist, but for those of us raised in inner-city poverty, the violence that our families experienced is as real as our support for police.

Mainstream Media (MSM) reports about hate crimes is often lop-sided and inaccurate; for instance, White-trash males are often accused of most mass shootings (Statistica, 2021). Whereas a review of the data from the Mother Jones website, reveals that Mass Shooters have many different hues. Arabs had 9 shooters, which is $7 \%$ of the total or $744 \%$ higher than Arabic percentages of the US population; 2 Native American shooters are 165\% higher; 21 Black shooters make 145\% higher; 8 Asian shooters are 110\% higher; and whites had 66 shooters which is $55 \%$ of the total, or $12 \%$ lower than their population total percentage (Mother Jones 2021).

\section{FIGURE 6 \\ EXPANDED HOMICIDE DATA}

\begin{tabular}{|c|c|c|c|c|c|c|c|c|c|c|c|}
\hline \multicolumn{12}{|c|}{$\begin{array}{l}\text { Murder } \\
\text { Race, Sex, and Ethnicity of Victim by Race, Sex, and Ethnicity of Offender, } 2019 \\
\text { [Single victim/single offender] }\end{array}$} \\
\hline & & \multicolumn{4}{|c|}{ Race of offender } & \multicolumn{3}{|c|}{ Sex of offender } & \multicolumn{3}{|c|}{ Ethnicity of offender } \\
\hline Race of victim & Total & White & $\begin{array}{l}\text { Black or } \\
\text { African } \\
\text { American }\end{array}$ & Other $^{1}$ & Unknown & Male & Female & Unknown & $\begin{array}{l}\text { Hispanic } \\
\text { or Latino }\end{array}$ & $\begin{array}{l}\text { Not } \\
\text { Hispanic } \\
\text { or Latino }\end{array}$ & Unknown \\
\hline White & 3,299 & 2,594 & \begin{tabular}{|l|}
566 \\
\end{tabular} & 56 & 83 & 2,915 & 359 & 25 & 738 & 1,542 & 1,019 \\
\hline Black or African American & 2,906 & 246 & 2,574 & 23 & 63 & 2,606 & 273 & 27 & 95 & 1,841 & 970 \\
\hline Other race $^{1}$ & 247 & 57 & 40 & 138 & 12 & 211 & 34 & 2 & 18 & 144 & 85 \\
\hline Unknown race & 126 & 51 & 38 & 8 & 29 & 107 & 17 & 2 & 23 & 47 & 56 \\
\hline
\end{tabular}

Similarly, there have been false claims of increasing white-trash violence against Asian people (Fadel, 2021). Using the published data, violent incidents committed against Asian victims by Asian offenders (24\%) was 3.9 times higher than the percentage of Asians in the population (6\%). Violent incidents committed against Asian victims by Black offenders (27\%) was 2.25 times higher than the representation of Black persons in the population (12\%). Violent incidents committed against Asian victims by White offenders (24\%) was 0.38 times less than the representation of White persons in the population (62\%). CRT advocates illogically assume that every arrest or police arrest is due to racism (Schwartz, 2021, page 72). Instead, CRT advocates should educate themselves on crime data and stop fear mongering - and those of us falsely accused by CRT advocates need to start filing civil lawsuits to stop the slander, defamation, and their manipulative propaganda (Morgan \& Oudekerk, 2018). 


\section{FIGURE 7 \\ VIOLENT INCIDENTS BY RACE OR ETHNICITY}

BJS 2018, TABLE 14: Percent of violent incidents, by victim and offender race or ethnicity, 2018

\begin{tabular}{|c|c|c|c|c|c|c|c|c|}
\hline $\begin{array}{c}\text { Victim Race- } \\
\text { Ethnicity }\end{array}$ & $\begin{array}{l}\text { Number of } \\
\text { Violent } \\
\text { Incidents }\end{array}$ & Total & $\begin{array}{r}\text { White } \\
\text { Perp }\end{array}$ & $\begin{array}{r}\text { Black } \\
\text { Perp }\end{array}$ & $\begin{array}{r}\text { Hispanic } \\
\text { Perp }\end{array}$ & $\begin{array}{l}\text { Asian } \\
\text { Perp }\end{array}$ & $\begin{array}{l}\text { Other } \\
\text { Perp }\end{array}$ & $\begin{array}{c}\text { Multiple } \\
\text { offenders of } \\
\text { various } \\
\text { races }\end{array}$ \\
\hline White & $3,581,360$ & $100 \%$ & $62.1 \%$ & $15.3 \%$ & $10.2 \%$ & $2.2 \%$ & $8.1 \%$ & $2.1 \%$ \\
\hline Black & 563,940 & $100 \%$ & $10.6 \%$ & $70.3 \%$ & $7.9 \%$ & $0.1 \%$ & $9.3 \%$ & $1.9 \%$ \\
\hline Hispanic & 734,410 & $100 \%$ & $28.2 \%$ & $15.3 \%$ & $45.4 \%$ & $0.6 \%$ & $7.4 \%$ & $3.0 \%$ \\
\hline Asian & 182,230 & $100 \%$ & $24.1 \%$ & $27.5 \%$ & $7.0 \%$ & $24.1 \%$ & $14.4 \%$ & $2.9 \%$ \\
\hline
\end{tabular}

Source: Bureau of Justice Statistics, National Crime Victimization Survey, 2018.

Obtained from: https://bjs.ojp.gov/content/pub/pdf/cv18.pdf

I previously wrote that my cousin was raped and then murdered, moments after her fiancé was executed by the same gang. This violence was never listed as a "hate crime" - one may assume due to political correctness and the race of the perpetrators. In addition, Reilly (2019) estimates that between 15 and 50 percent of widely reported hate crimes are frauds (Reilly, 2019, p. 142). For instance, a jury in Cook County, Ill., has found actor Jussie Smollett guilty of felony disorderly conduct for staging a fake hate crime, paying two people to carry out the attack in January of 2019 (Chappel \& Romo, 2021). So, the United States legal system already has a biased reporting system that does not tell the full story. I can only speak for my own white-trash family: we want the violent crimes to stop! Defunding the police does not make sense to those of us raised in the most violent portions of the inner city and defunding is not supported by Americans of all hues (Saad, 2020). The radical CRT advocates' rhetoric that the police are killing Black people because of their race is not supported by empirical study (Shane, Lawton, and Swenson, 2017). Yet, Black Lives Matter (BLM) calls for defunding the police have resulted in a 30\% rise in murder rates during 2020, showing that BLM does not really care about black lives (Riley, 2021; Stepman, 2021).

\section{A CRITIQUE OF CRITICAL RACE THEORY (CRT) FAULTY LOGIC}

The critical race theory arguments defy logic as was taught to me in junior high school. Perhaps our CRT theorists and advocates cut school that day, none-the-less, many popular stances do not hold up to scrutiny. Every language has an inner logic, and all races think logically (Jaja and Badey, 2012).

\section{Hasty Generalization}

A hasty generalization is an oversimplification about a class based upon a small or poor sample (Bluedorn, 2015, p. 141). Sometimes the sample for a generalization is large, but it isn't representative of the entire class; for instance, CRT advocates blame white people for slavery without acknowledging that only $1.26 \%$ of Americans owned slaves per the 1860 census. More than $98 \%$ of white families never owned a slave in 1860 and beyond (Census Bureau, 1860). One should question whether this narrative is merely a hasty generalization, or an intentional lie. This is also characterized as a 'Part to Whole' fallacy, for instance, just because part of the United States population owned slaves (1.26\% of the total; but 3.48\% of the South) does not mean that the remaining population $(98.74 \%)$ condoned it, was enriched by it, or continue to benefit from it. As stated in my ethnography, after being severely beaten, my mother taught me to despise the perpetrators, not an entire race; CRT teaches the opposite. 


\section{FIGURE 8 \\ 1860 CENSUS OF THE UNITED STATES}

\begin{tabular}{|r|c|c|c|c|c|c|}
\hline & Total population & Total FMC & Total White & Total \# Slaves & Total \# slaveholders & Owner \% \\
\hline Total North population & $22,078,250$ & 343,988 & $21,243,561$ & 402,436 & 77,343 & $0.35 \%$ \\
\hline Total South population & $9,105,332$ & 132,760 & $5,447,220$ & $3,548,110$ & 316,632 & $3.48 \%$ \\
\hline Total U.S. population & $31,183,582$ & 476,748 & $26,690,781$ & $3,950,546$ & 393,975 & $1.26 \%$ \\
\hline Percentages & $100.00 \%$ & $1.53 \%$ & $85.59 \%$ & $12.67 \%$ & $1.26 \%$ & \\
\hline
\end{tabular}

${ }^{\star} \mathrm{FMC}=$ Free Men of Color

CRT advocates do not acknowledge that one million European slaves were brought to North Africa, which was more numerous than the 388,000 African slaves brought into the United States (Curtin, P., 2003, p. 72-87; Davis, 2003; Eltis \& Engerman, 2011; Sowell, T., 2019, p. 221); in fact Europeans were being sold in Islamic slave markets decades after slavery was outlawed within the United States (Sowell, 2005, p. 112; Sowell, 2008, p. 161). But there is a dearth of objectivity and integrity among CRT advocates; hence, intentionally omitting important historical facts to shape their master narrative. The first British and American Social Justice Warriors were white abolitionists who ended slavery (Sowell, 2005, p. 117; Schwarz, 2021, p. 7) and they were supported by Quakers, Moravians, and Pietists (Strachan, 2021, p. 182) and other religious denominations petitioning Northern States to eliminate slavery prior to 1800 (Eltis \& Engerman, 2011, p. 625); but this does not fit the CRT narrative. White abolitionists were essential to the success of the underground railroad to combat slavery (Coffin, 1876). Furthermore, 600,000 soldiers died in the US Civil War that led to the liberation of black slaves, and most of the slain were white. In addition, white Republican abolitionists wrote and passed the $13^{\text {th }}, 14^{\text {th }}$ and $15^{\text {th }}$ Amendments; they wrote every Civil Rights Act from 1865 to 1964 (Jackson, 2009, p. 85).

Finally, according to the Tuskegee Institute, the Ku Klux Klan was created as a terrorist arm of former slave holders, who lynched 4,743 victims, consisting of 3,446 blacks (73\%) and 1,297 white abolitionists (27\%); any mention of white fatalities is conveniently omitted from 1619 project and other CRT-based propaganda. Yet, the total number of blacks killed by KKK over a period of 86 years is roughly equal to half of the annual number of blacks killed by blacks from 1999 to 2006 (Smith, 2011). Focusing only upon black victims of the KKK, without mention of white-abolitionist victims of the KKK, paints CRT propagandists as bigots or liars who have tried to paint a simplistically false picture of the oppressors and oppressed based only upon race. The CRT mantra that all blacks are victims, and all whites are oppressors can also be a proof-by-lack-of-evidence fallacy where CRT claims something is true simply because nobody has yet given them any evidence to the contrary; it is also quite like the NAZI belief that all Germans were good, and all Jews were bad, which is frightening.

\section{Appeal to the People Fallacy}

Author Peggy McIntosh has advocated her hasty generalization in writing and publishing a non-peer reviewed opinion piece called White Privilege: Unpacking the Invisible Knapsack. She has reinforced her message by committing an 'appeal to the people' fallacy. As previously stated, I am white-trash (a light skinned, multi-racial person) raised in a black neighborhood, and her checklist is meaningless to me as well as millions of other white-trash people. I took McIntosh's challenge and my responses out of 26 questions were 20-No; 1-Yes; 4-Not Always; and 1-Not Applicable. McIntosh presumes to be the voice of equality, but her opinion piece and checklist is both ironic and embarrassingly dishonest for millions of White-trash people who are in the lowest socio-economic quintile. If McIntosh wants to discuss equality, then she should consider using the checklist shown in Figure 2.

\section{Post-Hoc-Ergo-Propter-Hoc}

When one assumes that since A happened before B, then A must have caused B. Therefore, CRT advocates claim that since slavery (A) occurred before American economic growth (B), then slavery caused American economic prosperity. This is not a complex issue but is often used as an argument by CRT 
advocates for reparations. However, according to the Trans-Atlantic Slave Trade Database (Gates, 2017), the North American colonies imported a total of 388,000 slaves from Africa out of 11 to 12 million shipped, with the remainder delivered to the Caribbean and Latin America; another 14 million were shipped to the Caliphates (Sowell, 1994, p. 188). CRT claims that slavery caused US prosperity, but where are the economic superpowers in Latin America, Middle East, or North Africa? Using CRT advocates' flawed logic, if Brazil imported 5 million slaves, then Brazil should have an economy that is 12 times greater than that of the United States: they don't. Hint: correlation and causation have two different meanings.

\section{Faulty Assumptions}

An assumption is something taken for granted or accepted as true without proof (Bluedorn, 2015, p. 84). To avoid faulty assumptions, we must listen, evaluate our assumptions, and evaluate other people's assumptions to try to be as objective as we can. Faulty assumptions are common within CRT advocates' circles, for instance Kendi (2019) is allegedly against discrimination but he wrote:

- "If discrimination is creating equity, then it is antiracist."

- "The only remedy to racist discrimination is antiracist discrimination."

- "The only remedy to past discrimination is present discrimination."

- "The only remedy to present discrimination is future discrimination" (Kendi, 2019, p 19).

Within the echo chambers of CRT advocates, Kendi claims that his viewpoint is correct because many other people agree with it, hence he is also committing an 'appeal to the people' fallacy. Why would anyone of any hue agree that any kind of discrimination is antiracist? Anti-racism consists of indoctrinating people into believing Whites are racist simple because they are White (Hanson, 2020, p. 12) - the definition of bigotry!

\section{Either-Or Logic}

'Either-Or' faulty logic asserts that we must choose between two things, when in fact there are normally many more alternatives. CRT advocate Kendi claims that either you are a racist or you are an antiracist without any other alternatives. Kendi writes, "One endorses either the idea of a racial hierarchy as a racist, or racial equality as an antiracist ... (and) the claim of not racist neutrality is a mask for racism" (Kendi, 2019, p. 9), which is a faulty opinion that is an "Either-Or" logic fallacy. Another dishonest innovation is the redefining of words to sway an argument. Kendi does not use the commonly accepted definition of racist, which is a person who is prejudiced against or antagonistic toward people based on their racial or ethnic group. Instead, he attempts to redefine the American language, in a disingenuous attempt to support his premise:

- Racist: One who is supporting a racist policy through their actions or inaction or expressing a racist idea.

- Antiracist: One who is supporting an antiracist policy through their actions or expressing an antiracist idea (Kendi, 2019, p. 13).

Rather that structuring an argument based upon fact, CRT theorists and advocates often restructure definitions to support their arguments. Cynically, one can observe that all statements are true, if one is free to define their terms (Sowell, 1995, p. 102).

\section{Circular Arguments}

Circular Argument is also known as petitio principii or begging the question e.g., if one says $\mathrm{P}$ is true because $\mathrm{Q}$ is true, and Q is true because $\mathrm{P}$ is true. CRT theorists and advocates often use circular reasoning, which is a logical fallacy wherein one begins with what one is trying to end with, for example: "Whites must atone for being racist, by supporting anti-racism and CRT; if whites appose anti-racism and CRT then that is proof that they are racists." CRT/ANTIFA demonstrators will also claim that opposition to the Black Lives Matter (BLM) organization is proof of racism; however, anyone of any hue can genuinely believe that Black, Hispanic, Asian, and White lives matter, but still be opposed to the Marxist principles of the BLM founders. Supporting "all black lives" is not the same as rubber stamping the radical actions and beliefs of the BLM organization. 


\section{Tu Quoque Fallacy}

Tu quoque is Latin for "you too" (Bluedorn, p. 53). This fallacy happens when somebody claims that two wrongs make a right. The fact that somebody did something wrong to you doesn't mean you have a right to do the same back to them. Tu quoque is broadly connected to the concept of displaced anger, which is commonplace throughout the CRT community. When someone is angry, s/he will often take anger out on the person causing the pain. And if someone is unable to resolve anger, it may become displaced, meaning that it is directed towards something or someone else that has absolutely nothing to do with the original conflict. This is what was witnessed during the BLM and ANTIFA riots throughout 2020. A vigilante is an individual who sets out to enforce the law on his or her own and without official authorization: BLM and ANTIFA have become self-anointed vigilantes, who are supported by CRT advocates (Delgado, 2017, 124).

"Violence as a way of achieving racial justice is both impractical and immoral. It is impractical because it is a descending spiral ending in destruction for all. It is immoral because it seeks to humiliate the opponent rather than win his understanding; it seeks to annihilate rather than to convert. Violence is immoral because it thrives on hatred rather than love." - Martin Luther King, Jr.

\section{Manipulative Propaganda}

Manipulative propaganda is used when someone plays with our emotions in a way designed to make us agree with them without thinking through the matter carefully. Manipulative propaganda is like a red herring fallacy: it avoids the important issues that should be addressed; it distracts us (Bluedorn, 2015, p. 190). CRT advocate Ibram Kendi claimed that President Trump praised white supremacists as "very fine people" in the summer of 2017 (Kendi, 2019, p. 8). National Socialist Adolf Hitler once wrote that propaganda in war was a means to the end (Hitler, 1938, p. 81) and Kendi's false white supremacist assertion in his widely distributed book is easily proven defamatory propaganda. Trumps actual speech is quoted as follows:

"You had some very bad people in that group, but you also had people that were very fine people on both sides ... I saw the same pictures as you did. You had people in that group that were there to protest the taking down of, to them, a very, very important statue and the renaming or a park from Robert E. Lee to another name... So, you know what, it's fine. You're changing history. You're changing culture. And you had people - and I'm not talking about the neo-Nazis and the white nationalists, because they should be condemned totally - But you had many people in that group other than neo-Nazis and white nationalists" (Robbins, 2020).

The 1619 Project can be considered a propaganda arm of the CRT movement, designed elevate racial division (Wood, 2020, p 67). Many notable historians on the right and left have found that the factual accuracy of this work was ill-founded. Peter Woods (2020) has found that many of the 1619 Project's assertions were "simply false, and some were outrageously false" (Wood, 2020, p. 64). In contrast to CRT propagandists, Booker T. Washington once observed that "a lie doesn't become truth, wrong doesn't become right, and evil doesn't become good, just because it's accepted by a majority."

\section{Manipulative Propaganda Combined With Tu Quoque Fallacy}

Tu quoque happens when somebody claims that two wrongs make a right and manipulative propaganda is used to play with our emotions. These two logic fallacies are used effectively to end any discussion of affirmative action. Delgado (2017) does not consider affirmative action as a case of reverse discrimination against whites, because this would characterize whites as innocent (Delgado, 2017, page 91), claiming that very poor minorities differ in degree from poor white counterparts (Delgado, 2017, page 119) without providing any proof. The United States adopted affirmative action, via President Lyndon Johnson's 
Executive Order 11246 in 1965 (Johnson, 1965). Surprisingly, Delgado acknowledges that critics urge abolishing race-based in favor of economically based affirmative action to help kids of all hues, who grew up poor (Sowell, 2017, page 215). However, CRT advocates oppose poverty-based programs because the number of poor whites greatly exceeds POC who are impoverished (Delgado, 2017, page 133), hence they think two wrongs make a right.

CRT propaganda spins the Supreme Court decision from Michigan, Grutter v. Bollinger, 539 U.S. 306 (2003) saying that public universities, may operate narrow affirmative action programs aimed at creating a diverse intellectual climate (Delgado, 2017, page 131) without identifying the dissent. For instance, Justice Sandra Day O'Connor wrote that "race-conscious admissions policies must be limited in time." She added that the Supreme "Court expects that 25 years from now (in 2028), the use of racial preferences will no longer be necessary to further the interest approved today" (Riley, 2014, p. 145). And Chief Justice William Rehnquist argued that the university's admissions system was, in fact, a thinly veiled and unconstitutional quota system. There are now over 276 statutes that grant preferences in employment, benefits, or federal contracting to POC, so affirmative action in practice today is racial discrimination (Riley, 2014, p. 148; Lynch, 1991). In addition, Asians have entered the fray seeking true equality based on merit making them an inconvenient minority. When CRT advocates accuse my kids or other Asian Americans of privilege or white adjacency, they imply that "Asian Americans are taking things away from other races in an apparent zero-sum game to the top" (Xu, 2021, p. 210). Pure bigotry!

As explained in my autoethnography, I was the child who was raised in the lowest quintile of the socioeconomic spectrum. Please imagine a white-trash person from the bottom-quintile and a black man from an upper-quintile who are equally qualified, interviewing for the same position in a business. White-trash candidates consistently lose to middle class and upper income minorities with lower GPAs, whether in college admissions, race-based scholarships, or the affirmative action hire- and promotion-quotas imposed upon managers, e.g., low-class whites are the losers in the racial spoils system (Gonzalez, 2021, p. 58). Affirmative action is not reverse discrimination; it is 55 years of government-mandated systemic discrimination against the white-trash population, which balkanizes the country, stigmatizes poor whites, and violates the merit principle. This affirms that blackness itself has value for its possessor and conveys a host of privileges and benefits, such as affirmative action quotas and scholarships, as well as blind acceptance of POC perspectives by the media. Ironically, many whites do not speak out against affirmative action's systemic racism, for fear of being called racist. Projecting appears to be the primary response of CRT advocates; ostracizing dissenting opinion appears to be the norm (Wood, 2020, p. 23).

\section{CONCLUSIONS}

My autoethnography narrative reflects the reality that access to American privilege is economically, and not racially based. Barack Obama had a great childhood, an educated mother, and an extremely wealthy stepfather, international travel, and an Ivy League education. Barack had privilege; I did not. White-trash students who are being raised in black neighborhoods face racism, prejudice, and discrimination, as well as continuous hate speech and microaggressions that attack one's self-esteem and sense of identity. Application of CRT might somehow benefit people of color (not yet proven), but it simultaneously and adversely impacts upon whites in the lowest socio-economic quintile, and perhaps all quintiles. I argue that CRT theorists and systemic racism paradigms are based predominantly upon opinion and anecdotes while being devoid of substantive supporting facts in contrast to true systemic racism as shown in Figure 3 . This paper addressed preconceptions that marginalize white-trash people or conceal our humanity, which is a legitimate function of academic discourse.

My autoethnography represents a strong counternarrative to the master story that CRT advocates tell about white-trash families: we are not lazy and incompetent racists (neither consciously or unconsciously), who do not care about education or equality, nor are we mass murderers. This narrative is also a counter to the "whites are oppressors and blacks are victims" mantra because every race in the United States has an upper quintile who earn more than six-figures, as well as a lower quintile who typically earn the minimum wage. Whether Asian, Black, Hispanic, or White, the population in the top quintile have more in common 
with each other than members of their own race in the lowest quintile. The same is true across race and ethnicity in the bottom quintile.

In the USA there is not white privilege, but economic privilege that is primarily dependent upon the good or bad choices of one's parents. No one can argue that Barack and Michelle Obama's children have more privilege than any White-trash child bar none. Broad patterns of injustice to the lower-class, whitetrash in our societies is invisible to middle-to-upper class black people, but painfully obvious to the whitetrash people who are directly affected. Hence, my counter-narrative challenges the negative master narrative by highlighting personal struggles of a (mixed-race) white male against poverty and racism within a blackdominated school, neighborhood, and city. It also provides new insights to the many weaknesses of CRT theorists, who lack objectivity, and often default to hasty generalization fallacies and other logic flaws previously addressed.

As a person who spent 26 years in the military and 14 years in corporate America, I strongly recommend not adopting CRT or anti-racist training by either corporations or the military. The United States military is built upon merit, normally with the best officers and the best non-commissioned officers rising-up the ranks due to their competence, commitment, and integrity - not race. U.S. Army team building is a continuous process of improving effective teams who:

1) Trust each other and predict what each will do;

2) Work together to accomplish the mission;

3) Execute tasks thoroughly and quickly;

4) Meet and exceed the standard;

5) Adapt to demanding challenges;

6) Learn from experiences and develop pride in accomplishments (ATP 6-22.6, 2015).

Sadly, the implementation of CRT will not accomplish, nor be a catalyst, for any of these goals; it will have the opposite effects of strife and division (Strachan, 2021, p 71). Any military leader who supports CRT training to include the Chairman Joint Chiefs of Staff and the Combatant Commanders should literally be courts-martialed for violation of Title 18 US Code $\$ 2384$, Seditious Conspiracy, because application of CRT theory will destroy unit cohesion. e.g., Sedition is a conspiracy to engage in an unlawful act, such as the insurrection that started at the Capitol Hill Autonomous Zone (CHAZ) in Seattle; but it can also be construed as intentionally setting up military forces for failure. Any act that deliberately strengthens or tends to strengthen enemies of the United States, or that weakens or tends to weaken the power of the United States to resist and attack such enemies is characterized as aid and comfort. In the incidents of violence in Minneapolis, Seattle, and Portland, the BLM/ANTIFA demonstrators used an urban warfare strategy directly from Carlos Marighella's doctrine that prescribed turning political crisis into armed conflict (Williams, 1989; O'Neill, 2005). So, one can either conclude that Chairman, JCS is potentially incompetent or worse yet, a sympathizer who deliberately aided this internal threat. An investigation of the CJCS is warranted.

CRT is racial grievance indoctrination that was a catalyst for billions of dollars of property damage during the 2020 riots (Nester, 2020) and will result in racial animus within any organization whether military or civilian (Cordero, 2021; Wood, 2020, p. 107). Using a twisted Tu Quoque Fallacy, CRT advocate Hannah-Jones tried to justify these riots as an appropriate response to black oppression (Wood, 2020, p. 102). In contrast to Hannah-Jones biased assertion, Martin Luther King Jr. spoke at the Southern Methodist University in 1966:

"I say that a doctrine of black supremacy is as dangerous as a doctrine of white supremacy. God is not interested merely in the freedom of black men and brown men and yellow men, but God is interested in the freedom of the whole human race and the creation of a society where all men will live together as brothers." (King, 1966)

CRT advocates preach the opposite of Dr. Martin Luther King, Jr. without apology. For instance, Kendi (2019) admits that "we are not pursuing Martin Luther King's color-blind dream of a more or less raceneutral America" (Kendi, 2019, p. 178; Gonzalez, p. 134). It is my hope that the CRT theorists and 
advocates would read this autoethnography to dispel any notion that white, black, or brown are mono-lithic blocks of either oppressor or oppressed. We are all individuals - and our successes or failures cannot merely be judged based upon a person's pigment or CRT's unproven and bigoted theories.

CRT has become a political tool to oppress and divide "we the people." Unfortunately, White and Asian-American workers now face discrimination that is surprisingly similar to two types of sexual harassment: (1) 'quid pro quo' racial harassment of the majority, wherein their compliance with anti-Racist and critical race theories are now exchanged, or proposed to be exchanged, for an employment opportunity (often in lieu of being fired); and (2) the type of harassment that arises when overt racial harassment (disguised as CRT and anti-Racism) is a persistent condition of work, such as whites being forced to apologize for unproven and/or imaginary micro-aggressions and privileges. This is a violation of the First Amendment (free speech), the Fourteenth Amendment (equal protection), and the Civil Rights Act of 1964, as well as equality, justice, and common standards of human decency. I will not comply.

\section{EPILOGUE}

CRT theorists and advocates ignore the massive social and economic progress made by POC since 1964; our country elected and re-elected its first black president and has witnessed the progressive advance of gay rights. So, the following list of progress is based upon American Economic Privilege which, unlike Peggy McIntosh, can be supported by fact, and not just one woman's biased opinions. If the United States was genuinely a systemically racist country as portrayed by CRT advocates, then:

- the $13^{\text {th }}, 14^{\text {th }}$, and $15^{\text {th }}$ Amendments to the U.S. Constitution would never have passed.

- the Civil Rights Act and Voting Rights Act would not have been implemented.

- Barak Hussein Obama would not have become President of the United States.

- Colin L. Powell and Condoleezza Rice would not have been Secretary(s) of State.

- Ben Carson would not have become a neurosurgeon and Secretary of Housing and Urban Development.

- Eric Holder and Lorette Lynch would not have been appointed US Attorney General.

- the Congressional Black Caucus would not have been allowed to exist.

- the NAACP and HBCUs would not be allowed to exist nor funded by Federal taxes.

- Black mayors would not be running major cities throughout the United States.

- Kanye West's (Ye) would not be a Billionaire (est. \$3.2 billion).

- Oprah Winfrey would not be a Billionaire (est. $\$ 2.5$ billion).

- $\quad$ P-Diddy's net worth would not be approaching a billion (est. $\$ 885$ million).

- Jay-Z would not be a millionaire (almost billionaire).

- LeBron James' net worth would not be $\$ 480$ million (highest paid person in basketball).

- eighty percent of blacks in the USA would not be middle class or higher, yet they are!

- the NBA would not be $74 \%$ black (mostly millionaires).

- the NFL would not be $68 \%$ black (mostly millionaires).

- The USA would not have 780,000 black millionaires and 7 black billionaires, yet there are!

- approval of interracial marriage would not have risen from 4\% in 1950 to $90 \%$ in 2021.

- Dr. Martin Luther King Jr, Dr. Thomas Sowell, and Dr. Walter Williams would not have earned their advanced degrees during the 1950s and 1960s.

- Nigerian immigrants would not have more advanced degrees \& higher income than white people in the U.S. - note: Nigerian immigrant success is based on culture, not color.

- the U.S. Black population's combined income (Gross Domestic Product) would not be the equivalent of the $15^{\text {th }}$ largest nation out of 180 nations in the world. 


\section{The Fallacy of Non-Sequitur}

Critical Race Theory has many logic flaws as discussed previously, but perhaps the greatest flaw is the fallacy of non sequitur (it does not follow) that occurs when there is not even a deceptively plausible appearance of valid reasoning, as there is an obvious lack of connection between the given premises and the conclusions drawn. Critical Theory (CT), Critical Legal Theory (CLT), and Critical Race Theory (CRT) all have Marxist roots (CLSM, 2020), as do the BLM and ANTIFA organizers. BLM co-organizer Patrisse Cullors stated, "We actually do have an ideological frame ... [the co-founders] in particular are trained organizers, we are trained Marxists." (Freedom Forum, 2020). ANTIFA, who serve as foot-soldiers of the CRT/BLM movement also identify as anarchists and socialists (Nadales, 2020; Ngo, 2021; WND, 2017). So, their solution to societal wrongs is to tear down the current system and rebuild it in a new Marxist or Socialist image. Yet, if the United States was socialist, then the wealth of many POC in the forgoing bullets would belong to the state, not the individual. Furthermore, in the past century, tens of millions were being imprisoned, tortured, and subjected to forced starvation as a matter of socialist government policy (Coulter, 2003, p. 81); and over 100 million people were executed by socialist regimes wherein minorities in each of these socialist states suffered the most (Courtois et al., 1999). Therefore, based upon historical analysis, CRT is non sequitur because the solution of socialism would not correct the alleged problem of discrimination.

\section{Hypocrisy in Action}

Hypocrisy is the practice of claiming to have moral standards or beliefs to which one's own behavior does not conform. A simple example is when politicians direct their citizens to wear surgical masks but go on the town or host a party without wearing a mask (BBC, 2020). A more complex version hypocrisy is not little gaffs like forgetting a surgical mask, but instead proclaiming beliefs in Marxism and acting capitalist. Marx wrote that the power relationships between capitalists and workers were inherently exploitative and would inevitably create class conflict. Yet, shortly after all the BLM/ANTIFA protests decrying exploitation, one of the BLM cofounders bought four high-end homes for \$3.2 million (Vincent, 2021) and was looking for properties in the Bahamas as well. Although Patrisse Cullors is a public speaker, owns a small gallery, has a financial deal with YouTube, and teaches at a private liberal arts college; apparently protesting for Marxism and against capitalism has a rather large payoff. I know that many white-trash families would love to have a fraction of her wealth and real estate holdings - not bad for an oppressed Black woman, eh? BLM Marxist organizers talk the talk, but do not walk the walk!

Similarly, Coca-Cola was a poster child for capitalism, earning billions worldwide through its sales of carbonated sugar water. Yet, Coca-Cola executives have embraced the woke ideology and telling employees to be less white, which is blatant racism and discrimination (WION, 2021). White-trash people can exercise a privilege, which is the power to choose, and many are choosing to substitute Coca-Cola for a different product. Racism disguised as anti-racist training is still racism, and there should be stock market corrections related to this type of overt bigotry. I have switched brands. It is interesting that organizations, universities, and activist groups of all kinds announce that they are inclusive, but only of people who agree with them (Pluckrose \& Lindsay, 2020).

\section{FUTURE RESEARCH}

Personally, I cannot imagine a worse example of creating a self-fulfilling prophesy, than telling an impoverished young person of any race, that the deck is stacked against them. Yet CRT theorists and advocates do just that, while simultaneously ignoring the massive progress in every field that has occurred in the past 60 years. Similarly, they obfuscate many different issues, using twisted logic, partial truths and at times, blatant lies. It is time to end the racial animosity created by CRT propagandists and continuously strive for a nation that is focused upon merit and character, not color. Perhaps a first step would be for academic journals in the social sciences to conduct peer-reviews by unbiased reviewers instead of political hacks. Critical race theory failed in every category of logic discussed in this paper showing that it is neither critical nor factual, but merely anti-white racist propaganda. 
As a mixed-race member of the White-trash community, my Irish, Latino and African self, is quite embarrassed by the lack of intellectual acumen by members of the academic community who support CRT. The major intellectual failings of CRT theorists include non sequitur premises, hasty generalization, appeal to the people, post hoc ergo propter hoc, faulty assumptions, and tu quoque fallacies that are combined and interwoven with manipulative propaganda. Is there disparity in employment numbers? Yes. Are there differences in generational wealth? Yes. Are greater numbers of blacks arrested for committing violent crimes? Yes, but blacks commit half of all street crime in America (Elder, 2000, p. 41). CRT propagandists claim that this is a result of racism and sexism without looking at a myriad of other possibilities (Lynch, 1991, p. 151), such as: individual life choices, number of unwed mothers, number of high school dropouts or trade school dropouts, as well as the number of people who go to college and study social sciences, feminism, or ethnic studies rather than choosing a major in science, technology, engineering, math, or business (STEMB). One's degree and grade point average determine entry level wages after college, not skin color.

When income is normalized for experience, education, and geographic location, there are not massive disparities in income based on race or gender (Hattiangadi, 1998; Miller, 2021). In addition, there are no CRT controlled studies that look at number of hours worked and willingness to work overtime, types of work, levels of effort and motivation, or proof of intent to discriminate, which are required by Title VII.

\section{Ten Steps Toward White-Trash Equality, Inclusion, and Justice}

I grew up in a White-Trash culture of low income, few opportunities, and a dystopian neighborhood; I felt helpless. So, the following suggestions are geared to helping poor white-trash peoples, who often feel that they do not have the resources to evoke change.

1. White-trash people must follow the "success sequence" in this order - (a) getting at least a high school diploma; (b) working full-time; and (c) marrying before having any children. I am living proof that this will end poverty in just one generation (AEI, 2017).

2. Within capitalism, dollars are votes. White-trash peoples should not vote for companies like Coca-Cola that have accepted the CRT/anti-racism bigoted training against white or other employees.

3. White-trash people enlist in the military more than the upper class since it is a catalyst for upward mobility. White-trash veterans must petition the government to eliminate CRT/antiracism discrimination against whites in the armed forces. White-trash vets must advocate for the purge all senior leaders (Generals, Colonels, etc.) that support this racial bias and discrimination.

4. Academics must stop supporting a theory that is neither grounded in either fact, or logic. Social sciences should police their own professors and racially biased theories. If social sciences do not police themselves, then White-trash peoples must demand removal of social sciences as a required course in college.

5. A needed corrective step to stop defamation of white-trash people is a class-action, civil-lawsuit against any university, corporation, or government entity including military, that supports the CRT/anti-racism instigated bias and discrimination directed against the White-trash populations. Obviously, CRT is a violation of the First Amendment (free speech), the Fourteenth Amendment (equal protection), and the Civil Rights Act of 1964. CRT advocates are attempting to institutionalize (reverse) discrimination against the majority in a manner like affirmative action.

6. A new organization designed like the NAACP would benefit White-trash peoples, so that they attain equality in college admissions, scholarships, work, promotions, and government contracts - it might be called the National Association for the Advancement of White-trash (NAAWT) because White-trash males have borne the burden of affirmative action quotas since 1965.

7. Children of White-trash are in public schools simply because economically they have no other options; so White-trash parents must unify to demand school choice while we simultaneously 
protest and replace school boards that advocate CRT/anti-racism discriminatory theory and practice.

8. Read! White-trash people were typically born into the lowest economic strata, but that does not mean we are stupid, illiterate, or uneducated. E.g., Only by reading history would you learn that less than $2 \%$ of the US population owned slaves; $98 \%$ did not; and that whites led the abolitionist movements worldwide. This fact repudiates the CRT tenet that all whites are/were oppressors and all blacks are/were victims. White-trash males as well as any person of any gender or hue must never apologize for a wrong that was not committed! Refuse to take the knee! White-trash adults must teach their children to focus not upon emotions, but upon values and facts, since many public schools and universities have shifted from education to indoctrination.

9. White-trash people must reach out to become friends with a person who is non-white. Many White-trash people live in mixed neighborhoods, so this should not be difficult. The lowest quintile of blacks has more in common with the lowest quintile of whites than with the upper classes of either hue; discussions might focus simply on how we better protect our kids from crime and how to improve local schools.

10. Lastly, White-trash people should take the high road - without stooping to name calling and violence as was evident by CRT indoctrinated BLM/ANTIFA rioters from 2020 to 2021. White-trash people should be emulating and embracing Dr. Martin Luther King, Jr. calls for true equality, unity, and brotherhood across all races - always focusing on character, not color.

\section{"Darkness cannot drive out darkness; only light can do that. Hate cannot drive out hate; only love can do that." -Martin Luther King, Jr.}

FIGURE 9

\section{CRT GLOSSARY - AN ORWELLIAN ATTEMPT TO OBFUSCATE \& INDOCTRINATE}

\begin{tabular}{|c|c|}
\hline CRT's Orwellian Newspeak & Interpreting CRT Obfuscation \\
\hline $\begin{array}{l}\text { Antiracism: In woke thought, dedicated } \\
\text { opposition to hidden, race-based injustices } \\
\text { through social demonstration and political } \\
\text { activism; a white person cannot ever completely } \\
\text { escape internal racial bias but can perform } \\
\text { outward actions that seek to dismantle white } \\
\text { power. }\end{array}$ & $\begin{array}{l}\text { Antiracism is merely "anti-white racism" and makes } \\
\text { demands for anti-white discrimination. Antiracism } \\
\text { theorists ignore the progress of blacks and others in } \\
\text { the United States that has occurred in the past } 245 \\
\text { years; and inaccurately place racism as the blame for } \\
\text { every ill. }\end{array}$ \\
\hline $\begin{array}{l}\text { Color-Blindness: In woke thought, the false } \\
\text { claim often voiced by white people that they do } \\
\text { not evaluate others based on ethnicity or skin } \\
\text { color. }\end{array}$ & $\begin{array}{l}\text { Color-Blindness: Dr. Martin Luther King, Jr. was an } \\
\text { advocate for color blindness, asking people of all } \\
\text { colors to assess each other based on one's character. }\end{array}$ \\
\hline $\begin{array}{l}\text { Critical Race Theory (CRT): The system of } \\
\text { thought founded by legal scholars such as } \\
\text { Richard Delgado and Derrick Bell (circa 1989) } \\
\text { which asserts that hidden racism is pervasive } \\
\text { throughout society, all whites are racist, blacks } \\
\text { (and other minorities ) are not racist because } \\
\text { they lack the power to be so, and one's racial } \\
\text { group determines one's core identity; CRT's “ } \\
\text { solution " to the problem of racism is ( A ) to } \\
\text { deconstruct white power and (B) to redistribute } \\
\text { power to minorities. }\end{array}$ & $\begin{array}{l}\text { CRT asserts that Blacks (and others) are not racist } \\
\text { because they lack the power to be so. That is } \\
\text { nonsense! Black mayors have run major cities in the } \\
\text { USA for } 60 \text { years ... which makes them very } \\
\text { powerful. e.g., When Baltimore burned in } 2015 \text { over } \\
\text { death of a black man and alleged racism, the key } \\
\text { people in the arrest were black: the arresting } \\
\text { Sergeant, Police Commissioner, the Baltimore City } \\
\text { State's Attorney and Mayor, as well as the US } \\
\text { Attorney General and US President. The power was } \\
\text { vested in POC disproving this CRT tenet. }\end{array}$ \\
\hline
\end{tabular}


Critical Theory: The social philosophy pioneered by the work of Max Horkheimer and the Frankfurt School in Germany (circa 1930) which seeks to define and dismantle power imbalances that reside in the institutions and structures of society. CT and CRT Theorists are in favor of socialism.

Ethnic Gnosticism: Considered secret insider knowledge that a person possesses by being a member of a minority race; there are certain realities in society that a person can only know if he or she has a particular skin color.

Intersectionality: The crisscrossing of categories of oppression in society, including race, class, gender, sexuality, age, ability, citizenship, and body type; in intersectional thought, the most oppressed person is a black, poor, LGBT, young, disabled, undocumented, fat woman.

Microaggression: The voicing of a subtle and unintended stereotype (for example, “I don't see color") that implies power over ethnic minorities and elicits a negative reaction.

Racism: Historically, this term refers to any unfavorable or hostile attitude harbored by an individual based on a person's skin color; in woke thought, this term denotes race - based prejudice against someone only when it is coupled with power (e.g., prejudice plus power), such that an individual cannot display racism if he or she is an ethnic minority.

Social Justice: Historically, this phrase refers to broad attempts to fight against unfair inequalities that exist in civic life and to hold unjust perpetrators accountable; in woke thought, this phrase alludes to the twofold practice of deconstructing white power and redistributing power to minorities.

Standpoint Epistemology: The view that an individual's minority status gives him or her the unique ability to see truth in society, a perspective which is not able to be seen by a person in the majority group.
Capitalism is based upon meritocracy; but socialism is based upon equality of outcome. Critical Theory is based upon Marxism and as such promotes the belief that blacks, and other minorities cannot make it without government intervention. That is absurd! In the USA, there are 780,000 black millionaires and 7 black billionaires who prove otherwise.

Ethnic Gnosticism is an unproven hypothesis that there are certain realities that a person can only know if he or she has a particular skin color; laughable! There are socio-economic differences in society that are experienced if you are poor.

Intersectionality is a newspeak concept whereby one competes to be more oppressed than another. Yet, based on affirmative action, the most oppressed person is a white trash, male who has been forgotten by the legal system and is continuously attacked by CRT advocates.

Microaggression is not aggression (e.g., hostile, injurious, or destructive behavior). Words are NOT violence; if words were violence, then all CRT advocates would have been arrested already.

Racism is a belief that race is a key determinant of human traits and capacities and that racial differences produce an inherent superiority of a particular race; whereas discrimination is the practice of unfairly treating a person or group of people differently from other people or groups of people. CRT advocates practice racism and discrimination against whites.

Social Injustice: Historically, this refers to attempts to fight against unfair inequalities as doctrine of egalitarianism. However, CRT advocates abandoned egalitarianism for advocacy of anti-white retaliation. Social Justice Warriors are not "warriors" but vigilantes, who believe in retaliation not "justice" for perceived, not actual wrongs.

Standpoint Epistemology: My ethnographic study and unique minority status as a white person in a black neighborhood gave a perspective that cannot be seen by majority blacks in any major city; the pervasive racism in CRT denies a voice to poor white trash. 
Systemic Racism: Historically, this phrase refers to any explicit and sweeping societal policies that intentionally limit or segregate human beings based on race (for example, Jim Crow laws, neighborhood redlining, etc.); in woke thought, this phrase denotes the idea that race - based injustices are secretly embedded in the laws, policies, values, histories, institutions, language, and even thought categories created by the dominant white race.

\section{White Fragility: In woke thought, the defensive reaction that white people display when confronted with the reality of their racist attitudes; such a reaction can manifest in outbursts of anger, tears, anxiety, or even flight from the conversation.}

White Guilt: In woke thought, the shame that a white person feels for being part of the oppressor race.

White Privilege: In woke thought, the natural, inborn advantages, and benefits that all white people possess simply by virtue of being members of the dominant race.

White Supremacy: Historically, this phrase refers to overt declarations of racial superiority by advocates of race-based segregation, including movements such as the KKK and altright pro-Aryan groups; in woke thought, this phrase denotes the unspoken assumption possessed by all white people that they are the ideal race, and all other ethnicities are inferior. Whiteness: In woke thought, the mindset and lived reality of people with Indo-European ancestry and light-colored skin who view themselves, whether consciously or subconsciously, as the superior race and the embodiment of what every human culture should become.

Wokeness: The state of being consciously aware of and "awoke" to the hidden, race-based injustices that pervade all of American society; this term has also been expanded to refer to the state of being "awake" to injustices that are gender-based, class-based, etc.
There was systemic racism in the United States, but it has been dismantled. It is undeniable that democrats supported the KKK and Jim Crow laws. But it is equally undeniable that both abolitionists \& Republicans fought KKK and Jim Crow creating Civil Rights Acts in the 1800s as well as the 13th, 14th \&a 15th Amendments, plus the Equal Pay Act (1963), Title VII of the Civil Rights Act (1964), Voter Rights Act (1965), as well as the Americans with Disabilities Act (1990). These laws removed institutionalized racism.

White Fragility is slander. White people display defensiveness when accused of racism, simply because they abhor slander and defamation. There is no tangible, measurable proof of widespread racist attitudes among whites within the USA in 2022.

White Guilt is Slander: White people typically do not feel shame for imagined oppression; white guilt exists only among the mental ill. White abolitionists in UK and USA were the catalysts for eliminating slavery throughout most of the world - we have no shame. Economic Privilege: Affirmative action has systemically discriminated against White-trash individuals for 55 years; privilege in the United States is based on economics, not race.

Merriam-Webster defines white supremacy: the belief that the white race is inherently superior to other races and that white people should have control over people of other races. Both NAZIs and the KKK practiced white supremacy, but White Trash people and the average American does not. Concepts an "unspoken assumptions" are delusional hypothesis that cannot be measured.

Blackness: Black privilege is a right or advantage, often unwritten, conferred on some people but not others, usually without examination or good reason; it includes benefits, such as affirmative action quotas and race-based scholarships, a system by which blacks help and buoy each other up; it may include calls for boycotting white businesses and the torching of businesses or government buildings without repercussion.

Awakened: White Christians who started the abolitionist movement were the original "woke" movement. White abolitionists who started the Republican Party, won office, and wrote all civil rights legislation were woke. Demonstrators today are merely violent agitators and vigilantes. 


\section{ACKNOWLEDGEMENTS}

This paper is dedicated to my mother who taught me to despise the criminals, not an entire race despite many instances of assault, rape, and murder of our family members; she also taught me the art of forgiveness.

I am also grateful to Master Sergeant James Johnson, a soldier with a big heart, who gave me the blackboy speech, and kicked me in the butt when I needed it - he was the father that I did not have at home.

\section{REFERENCES}

American Community Survey (ACS). (2019). S0201: Selected Population Profile in the United States. Washington, D.C.: United States Census Bureau.

American Enterprise Institute (AEI). (2017). Millennial Success Sequence. Retrieved July 17, 2021, from http://www.aei.org/wp-content/uploads/2017/06/IFSMillennialSuccessSequence-Final.pdf

Army Training Pamphlet (ATP) 6-22.6. (2015). Army Team Building. Retrieved July 17, 2021, from https://armypubs.army.mil/epubs/DR_pubs/DR_a/pdf/web/atp6_22x6\%20FINAL.pdf

BBC News. (2020, September 3). Nancy Pelosi seen without mask inside San Francisco hair salon [Online]. Retrieved September 3, 2020, from https://www.bbc.com/news/world-us-canada53994209

Bluedorn, N., \& Bluedorn, H. (2015). The Fallacy Detective: Thirty-Eight Lessons on How to Recognize Bad Reasoning. Kindle Edition.

Bureau of Justice Statistics (BJS). (2018). National Crime Victimization Survey, 2018. Retrieved September 17, 2021, from https://bjs.ojp.gov/content/pub/pdf/cv18.pdf

Capretto, L. (2014). You're never Black enough: Colorism: Light-Skinned African-American Women Explain the Discrimination They Face. The Huffington Post. Retrieved January 13, 2014, from www.huffingtonpost.com/entry/colorism-discrimination-iyanla-vanzant_n_4588825.html

Chappel, B., \& Romo, V. (2021). Jussie Smollett found guilty of lying to authorities in trial over his alleged attack. National Public Radio. Retrieved December 9, 2021, from https://www.npr.org/2021/12/09/1062768250/jussie-smollett-verdict

CLSM. (2020). Critical Legal Studies Movement. Retrieved December 3, 2020, from https://cyber.harvard.edu/bridge/CriticalTheory/critical2.htm.

Coffin, L. (1876). Reminiscences of the Reputed President of the Underground Railroad. London, U.K.: Sampson Low, Marston, Searle, \& Rivington.

Cooper, A., \& Smith, E.L. (2011). U.S. Department of Justice, Homicide Trends in the United States, 1980-2008. Retrieved July 17, 2021, from https://bjs.ojp.gov/library/publications/homicidetrends-united-states-1980-2008\#: :text=2009\%20and\%202010.,Presents\%20findings $\% 20$ from $\% 20$ data $\% 20$ on $\% 20$ homicides $\% 20$ that $\% 20$ occurred $\% 20 \mathrm{in}$, States $\% 20$ from $\% 201980 \% 20$ through $\% 202008 . \&$ text=Based $\% 20$ on $\% 20$ data $\% 20$ from $\% 201980$,females $\% 20(3.4 \% 20$ per\%20100\%2C000)

Cordero, M. (2021). Critical Race Theory in the Military: How woke policies like CRT would destroy the military. The Heritage Foundation. Retrieved December 31, 2021, from https://www.heritage.org/defense/heritage-explains/critical-race-theory-the-military

Coulter, A. (2003). Treason: The Liberal Treachery from the Cold War to the War on Terrorism. New York: Three Rivers Press.

Courtois, S., Werth, N., Panne, J.L., Packowski, A., Bartosek, K., \& Margolin, J.L. (1999). Black Book of Communism: Crime, Terror, Repression. Cambridge, MA: Harvard University Press.

Crenshaw, K. (1991). Mapping the Margins: Intersectionality, Identity Politics, and Violence against Women of Color. Stanford Law Review, 43(6), 1241-1299.

Crenshaw, K.W. (2017). Race Liberalism, and the Deradicalization of Racial Reform. Harvard Law Review, 9(130), 2298-2319.

Curtin, P. (1969). The Atlantic Slave Trade: A Census. Madison: University of Wisconsin Press. 
Davis, R.C. (2003). Christian Slaves, Muslim Masters: White Slavery in the Mediterranean, the Barbary Coast, and Italy, 1500-1800. New York: Palgrave Macmillan.

Delgado, R., \& Stefancic, J. (2017). Critical Race Theory: An Introduction (Third Edition). New York University Press, New York City.

Du Bois, W.E.B. (1994). The Souls of Black Folk. New York, Avenel, NJ: Gramercy Books.

Elder, L. (2000). The Ten Things You Can't Say in America. New York: St. Martin's Press.

Eltis, D., \& Engerman, S.L. (2011). The Cambridge World History of Slavery: Volume 3, 1420-1804 AD. Cambridge, U.K.: Cambridge University Press. Kindle Edition.

Fadel, L. (2021). With racial attacks on the rise, Asian Americans fear for their safety. Heard on All Things Considered, National Public Radio. Retrieved October 22, 2021, from https://www.npr.org/sections/health-shots/2021/10/13/1045746655/1-in-4-asian-americansrecently-feared-their-household-being-targeted-poll-finds

Fisch, A. (2007). The Cambridge companion to African American slave narrative. Cambridge, UK: Cambridge University Press.

Freedom Forum. (2020). BLM Co-Founder Admits: We Are Trained Marxists. Retrieved December 31, 2021, from https://www.youtube.com/watch?v=p7C6tNjiRKY

Gates, H.L., Jr. (2017). 100 Amazing Facts About the Negro. Knopf Doubleday Publishing Group. Kindle Edition. Retrieved August 8, 2021, from https://www.openculture.com/2016/06/the-atlanticslave-trade-visualized-in-two-minutes.html

Gonzalez, M. (2021). The Plot to Change America: How Identity Politics is Dividing the Land of the Free. Encounter Books. Kindle Edition.

Halbrook, S.P. (2013). Gun Control in the Third Reich - Disarming the Jews and Enemies of the State. The Independent Institute.

Hanson, J. (2020). The Myth of White Fragility: A Field Guide to Identifying and Overcoming the Race Grifters. NYC: World Peace Publishing. Kindle Edition.

Haskins, R. (2013). Three Simple Rules Poor Teens Should Follow to Join the Middle Class. Retrieved July 17, 2021, from http://brook.gs/2bXvP8i

Hattiangadi, A.U. (1998). Where's My 26 Cents? Employment Policy Foundation. Retrieved June 30, 1998, from www.epf.org

Hitler, A. (1938). My Struggle. The Paternoster Library, London.

Jackson, K. (2009). The Big Black Lie: How I Learned the Truth about the Democrat Party. Kindle Edition.

Jaja, J.M., \& Badey, P.P. (2012, April). Logic in African Philosophy: Examples from two Niger Delta Societies. International Journal of Academic Research in Business and Social Sciences, 2(4).

Jennings, M.E. (2017). Is This How It Was Meant to Be? Autoethnography as Counter story in the Education of an African American Male. Journal of African American Males in Education, 5(2), 215-229.

Johnson, L.B. (1965). Executive Order 11246. Retrieved December 11, 2021, from https://www.dol.gov/agencies/ofccp/executive-order-11246/regulations

Kendi, I.X. (2019). How to Be an Antiracist. New York: Random House Publishing Group. Kindle Edition.

King, M.L., Jr. (1966, March 17). Speech at the Southern Methodist University. Retrieved July 17, 2021, from https://www.smu.edu/News/2014/mlk-at-smu-transcript-17march1966

Lesperance, D. (2020). Critical Race Theory: An Introduction from a Biblical and Historical Perspective. Kindle Edition.

Lott, J.R. (2000). More Guns, Less Crime: Understanding Crime and Gun-Control Laws. Chicago: The University of Chicago Press.

Lynch, F.R. (1991). Invisible Victims: White Males and the Crisis of Affirmative Action. New York: Praeger and Greenwood Publishing.

124 Journal of Leadership Accountability and Ethics Vol. 19(1) 2022 
Martin, J.A., Hamilton, B.E., Osterman, M.J.K., Driscoll, A.K., \& Drake, P. (2018, January 31). Births to unwed mothers. National Vital Statistics Reports, 1(67). Retrieved from https://www.cdc.gov/nchs/data/nvsr/nvsr67/nvsr67_01.pdf

McIntosh, P. (1989). White Privilege: Unpacking the Invisible Knapsack. Peace and Freedom. Retrieved July 17, 2021, from https://psychology.umbc.edu/files/2016/10/White-Privilege_McIntosh1989.pdf

Miller, S. (2020). Black Workers Still Earn Less than Their White Counterparts. Society for Human Resources Management (SHRM). Retrieved June 11, 2020, from https://www.shrm.org/resourcesandtools/hr-topics/compensation/pages/racial-wage-gapspersistence-poses-challenge.aspx

Morgan, R.E., \& Oudekerk B.A. (2018). Criminal Victimization. National Crime Victimization Survey (NCVS). Retrieved October 1, 2021, from https://www.bjs.gov/content/pub/pdf/cv18.pdf

Mother Jones. (2021). A Guide to Mass Shootings in America. Retrieved November 22, 2021, from https://www.motherjones.com/politics/2012/07/mass-shootings-map/

Nadales, G. (2020). Behind the Black Mask: My Time as an Antifa Activist. Bombardier Books. Kindle Edition.

Nester, A. (2020). Nationwide Protests Caused Up to \$2 Billion in Property Damage. The Washington Free Beacon. Retrieved November 22, 2021, from https://freebeacon.com/latestnews/nationwide-protests-caused-up-to-2-billion-in-property-damage/

Ngo, A. (2021). Unmasked: Inside Antifa's Radical Plan to Destroy Democracy. New York: Hachette Book Group (Kindle Edition).

O’Neill, B.E. (2005). Insurgency and Terrorism. Washington, D.C.: Potomac Books.

Pew Research Center. (2017). Intermarriage in the U.S. 50 Years After Loving v. Virginia. Retrieved July 17, 2021, from https://www.pewresearch.org/social-trends/2017/05/18/2-public-views-onintermarriage/

Pluckrose, H., \& Lindsay, J.A. (2020). Cynical theories: How activist scholarship made everything about race, gender, and identity-and why this harms everybody. Durham, NC: Pitchstone Publishing. Kindle Edition.

Reilly, W. (2019). Hate Crime Hoax: How the Left is Selling a Fake Race War. Washington, D.C.: Regnery Publishing. Kindle Edition.

Riley, J.L. (2014). Please Stop Helping Us: How Liberals Make It Harder for Blacks to Succeed. New York: Encounter Books.

Riley, J.L. (2021, December 8). The Predictable Consequences of Defund the Police. Wall Street Journal - Online Edition, N.PAG. Retrieved December 8, 2021, from

https://www.wsj.com/articles/consequences-of-defunding-the-police-libby-schaaf-violent-crimerate-murder-public-safety-11638915238

Robbins, J.S. (2020). Trump did condemn white supremacists, too bad so many people won't listen. USA Today. Retrieved October 2, 2020, from https://www.usatoday.com/story/opinion/2020/10/02/trump-and-white-supremacy-he-didcondemn-and-has-repeatedly-column/5883336002/

Saad, L. (2020). Black Americans Want Police to Retain Local Presence. Gallop Polling. Retrieved July 18, 2021, from https://news.gallup.com/poll/316571/black-americans-police-retain-localpresence.aspx?utm_source=tagrss\&utm_medium=rss\&utm_campaign=syndication

Schwartz, D.M. (2021). The Cult of Critical Theory: Slaying the false narratives of Systemic Racism, White Fragility, The 1619 Project, Breonna Taylor, Critical Race Theory, Eric Garner, Michael Brown and more. Kindle Edition.

Shane, J.M., Lawton, B., \& Swenson, Z. (2017). The prevalence of fatal police shootings by U.S. police, 2015-2016: Patterns and answers from a new data set. Journal of Criminal Justice, (52), 101111. Retrieved August 8, 2021, from https://www.sciencedirect.com/science/article/abs/pii/S0047235217301344

Sowell, T. (1994). Race and Culture: A World View. New York: Basic Books. 
Sowell, T. (1995). The Vision of the Anointed. New York: Basic Books.

Sowell, T. (2005). Black Rednecks \& White Liberals. San Francisco: Encounter Books. Kindle Edition

Sowell, T. (2008). Economic Facts and Fallacies. New York: Basic Books.

Sowell, T. (2019). Discrimination and Disparities. New York: Basic Books.

Statistica. (2021). Number of mass shootings in the United States between 1982 and November 2021, by shooter's race or ethnicity. Retrieved November 22, 2021, from

https://www.statista.com/statistics/476456/mass-shootings-in-the-us-by-shooter-s-

race/?fbclid=IwAR1rUGcOxH-Q3KBZvFGCbHFNgyRrbaPlZ3d7SKHarnTZbpan3oZynJrzMeU

Steele, S. (2006). White Guilt. HarperCollins e-books. Kindle Edition.

Stepman, J. (2021). FBI Statistics Show a 30\% Increase in Murder in 2020. More Evidence That

Defunding Police Wasn't a Good Idea. Heritage Foundation Online. Retrieved September 30,

2021, from https://www.heritage.org/crime-and-justice/commentary/fbi-statistics-show-30-

increase-murder-2020-more-evidence-defunding

Stepto, R. (1991). From behind the veil: A Study of African American Narrative (2nd ed.). Champaign, IL: University of Illinois Press.

Strachan, O. (2021). Christianity and Wokeness: How the Social Justice Movement Is Hijacking the Gospel - and the Way to Stop It. Washington, D.C.: Salem Books. Kindle Edition.

Tarlebbea, N.K. (2010). An Ethnographic Study on the Role of Education and Language among African Immigrants as they Struggle to Integrate and Succeed in the United States. Journal of Alternative Perspectives in the Social Sciences, 2(2), 854-868.

Tate, M. (2021). Choice Privilege: What's Race Got to do with it? Maitland, FL: Liberty Hill Publishing. Kindle Edition.

The World Bank. (2021). Gross Domestic Product (GDP) per capita. Retrieved 22 November 22, 2021, from https://data.worldbank.org/indicator/NY.GDP.PCAP.CD

U.S. Census Bureau. (1860). 1860 Census: Population of the United States. Retrieved July 17, 2021, from https://www.census.gov/library/publications/1864/dec/1860a.html

U.S. Census Bureau. (n.d.). Income By Race. Retrieved July 17, 2021, from https://www.census.gov/data/tables/time-series/demo/income-poverty/historical-incomepeople.html

U.S. Census Data, American FactFinder. (2021, July 17). Selected Economic Characteristics. Retrieved from https://factfinder.census.gov/faces/tableservices/jsf/pages/productview.xhtml?pid=ACS_17_ 5YR_DP03\&src=pt

U.S. Senate. (2000). S.HRG. 106-631. Hearing of the Committee on Health, Education, Labor, and Pensions - United States Senate. Washington, D.C.: US Government Printing Office.

Vincent, I. (2021). Inside BLM co-founder Patrisse Khan-Cullors' million-dollar real estate buying binge. New York Post. Retrieved April 10, 2021, from https://nypost.com/2021/04/10/inside-blm-cofounder-patrisse-khan-cullors-real-estate-buying-binge/

Williams, J.W. (1989, January). Carlos Marighella: The father of urban guerrilla warfare. Terrorism, 12(1), 1-20.

WION News. (2021). Coca-Cola promotes anti-white rhetoric, invites backlash. WION Web Team. Retrieved February 20, 2021, from https://www.wionews.com/world/coca-cola-promotes-antiwhite-rhetoric-invites-backlash-365070

WND Special Report. (2017). Antifa: What Americans Need to Know about the Alt-Left. WND. Kindle Edition.

Wood, P. (2020). 1620: A Critical Response to the 1619 Project. New York: Encounter Books.

World Economic Forum (WEF). (2020). The Global Social Mobility Report 2020: Equality, Opportunity, and a New Economic Imperative by the World Economic Forum. Retrieved December 31, 2020, from https://www3.weforum.org/docs/Global_Social_Mobility_Report.pdf

Xu, K. (2021). An Inconvenient Minority: The Attack on Asian American Excellence and the Fight for Meritocracy. New York: Diversion Books. Kindle Edition. 